\title{
An Assessment of Credit Risk Management Practices of Adansi Rural Bank Limited
}

\author{
Alexander Ayertey Odonkor ${ }^{1}$ \\ ${ }^{1}$ School of Business, Kwame Nkrumah University of Science and Technology, Kumasi, Ghana \\ Correspondence: Alexander Ayertey Odonkor, Kwame Nkrumah University of Science andTechnology, UP \\ 1660,KNUST, Ghana.Tel:233-547-875-325.E-mail: aaodonkor@ st.knust.edu.gh
}

Received: September 23, 2018

Accepted: October 29, 2018

Online Published: October 30, 2018

doi:10.5539/ijef.v10n11p110

URL: https://doi.org/10.5539/ijef.v10n11p110

\begin{abstract}
Rural banks in Ghana are not exempted from the risk exposures associated with managing credit. Given their importance to the economy, appropriate measures should be taken to mitigate credit risk exposures of rural banks in the country. The study critically examines the credit risk management practices of rural banks in Ghana making reference to Adansi Rural Bank Limited. The study was carried out to examine the credit management practices, credit policies and strategies for managing credit as well as challenges faced in this practice and to recommend solutions that will mitigate the credit risk exposures of Adansi Rural Bank Limited. The researcher used a purposive sampling technique to select a sample size of forty respondents which comprised of branch managers and credit officers from four different branches of the rural bank. The researcher used a well structured questionnaire and a face to face interview to collect primary data for this study. The researcher employed both primary and secondary data in the study. Descriptive statistical tools were used in analysing the data collected. The researcher discovered that Adansi Rural Bank Limited had implemented a rigorous credit risk management policy. This included; loan appraisal, use of collateral and checking the credit history of borrowers. The results of the study revealed that, rural banks that have implemented rigorous credit risk management policies were exposed to few challenges in managing credit risk as compared to rural banks with poorly implemented credit risk management policies. This affirms the point that a comprehensive credit risk management system should be adopted and implemented well by rural banks in Ghana.
\end{abstract}

Keywords: banking regulations, Basel II, credit risk, financial institutions, Ghana, rural banks

\section{Introduction}

\subsection{Background of the Study}

The financial sector of Ghana has contributed immensely to the growth of the country's fledgling economy. The financial sector has increased Ghana's economic growth through the provision of credit facilities to individuals and business enterprises. The availability of innumerable financial institutions in the last two decades has increased the demand for either short or long term credit facilities in Ghana. Among the many financial services rendered by banks, credit creation is the major income generating activity for the banks. However credit creation is known to expose the borrower and the lender to a higher risk. Credit risk is the possibility of losing the outstanding loan either part or the total amount, due to credit events (Basel Committee on Banking Supervision, 2011) and (Gostineau, 2013).The risk of a borrower not satisfying his or her obligation as per the agreement can greatly hold back the smooth functioning of a bank's operation. On the other hand, a bank with a high level of credit risk faces possible insolvency and this does not boost depositors' confidence to place deposits with it. A number of financial institutions have collapsed or encountered financial harms due to poor credit risk management systems coupled with high levels of insider lending, and high concentration of credit in a particular sector of the economy among other issues. Ineffective credit risk management practices and poor credit quality continue to be a leading cause of bank failures and banking crises worldwide. Credit management refers to the efficient blend of the four major credit policy variables to ensure prompt collection of loans granted to customers and at the same time boost their confidence in and loyalty to the bank (Van, 2010). The first variable is the assessment of the quality of the account of the customer. This assesses the ability of the customers to repay on time. The setting of the credit period is the second policy variable. In carrying out this activity, the bank has to give the customers a practicable time frame to derive full benefit from the credit they received. It should be 
noted that a longer time frame will be a demerit to the bank.

Discount or the enticement given to credit beneficiaries to repay credit on time is considered as the third variable. The discount or the enticement should be motivating enough before the arduous target can be achieved. The expenditure level that could be incurred in the collection exercise is the last variable. This indicates that the bank should not grant credit where the amount to be disbursed on collecting the debt will be greater than the debt. To blend these variables into an efficient workable system requires careful planning, controlling and co-ordination of all available human and material resources. Credit management involves establishing formal legitimate policies and procedures that will ensure that: the proper authorities grant credit, the credit goes to the right people, the credit is granted for the productive activities or for businesses which are economically and technically viable, the appropriate size of credit is granted, the credit is recoverable and there is adequate flow of management information within the organization to monitor the credit activity (Asiedu-Mante, 2011). Office of the Comptroller of the Currency (2011) however defined Loan portfolio management as the process by which risks that is inherent in the credit process are managed and controlled. It involves evaluating the steps the management of a bank takes to identify and control risk throughout the credit process.

The assessment focuses on what management does to identify issues before they become problems. Office of the Comptroller of the Currency identified nine elements that should be part of a loan portfolio management process and these elements are; Assessment of the credit culture, Portfolio objectives and risk tolerance limits, Management information systems, Portfolio segmentation and risk diversification objectives, Analysis of loans originated by other lenders, Aggregate policy and underwriting exception systems, Stress testing portfolios, Independent and effective control functions and lastly, Analysis of portfolio risk or reward trade-offs. Guidelines for Commercial Banks for Ghanaian Banks (2009) also see credit management as managing credit risk where credit risk arises from the potential that an obligor is either unwilling to perform an obligation or its ability to perform such obligation is impaired resulting in economic loss to the bank. According to Risk Management Guidelines for Commercial Banks \& DFIs (2009) a typical Credit risk management framework in a financial institution may be broadly categorized into the following main components.

- Board and senior Management's Oversight.

- Organizational structure.

- Systems and procedures for identification, acceptance, measurement, monitoring and control risks.

When it comes to lending activities of financial institutions, banks are guided by credit policies that are usually strategies and measures that are taken to guarantee smooth lending activities and loan repayment. If credit facilities are not assessed properly, there is the likelihood of credit risk because borrowers would default in loan repayment (Feder \& Justo, 1980).

\subsubsection{Problem Statement}

Rural banks are widely known as banks for the poor because they make funds available to individuals, small and medium-sized enterprises who do not qualify to assess loans from the universal banks. If rural banks are taking up huge credit risks, how do they manage the risk they are exposed to in order to make profit and stay in business? What credit risk policies are adopted to mitigate the credit risk rural banks are exposed to and the effect of the credit risk policies on loan portfolios? Credit risk management practices is an issue of uttermost concern in financial institutions today and there is a need to develop improved systems to deliver better visibility into future performance.

For many decades now, the most appropriate credit risk management technique a financial institution has to adopt has taken many diverging views from researchers. According to Owusu (2008) on credit risk management practices in rural banks in Ghana. He discovered that the appraisal of credit applications did not effectively assess the inherent credit risk. In his recommendation he pointed out that credit should be carefully evaluated for identified projects. Mwirigi (2006) on the other hand stated that loan portfolio management and operational efficiency management are the most important to consider in credit risk management as they are the most important in enhancing performance. The ultimate goal of this study is to identify the effects of credit risk management techniques and strategies on the performance of loan portfolio of Adansi Rural Bank Limited.

\subsubsection{General Objective}

The cynosure of the study is to assess the credit risk management practices adapted by Adansi Rural Bank Limited and how it affects the performance of their Loan Portfolio. 


\subsection{Specific Objectives}

Specifically, the research objectives are to;

1) Examine the credit risk policy of Adansi Rural Bank Limited.

2) Evaluate lending, monitoring and interventions used by Adansi Rural Bank Limited to recover overdue credit.

3) Identify the challenges encountered by Adansi Rural Bank Limited in the management of credit risk.

\subsubsection{Research Questions}

The study seeks to address the following;

1) What is the credit risk policy of Adansi Rural Bank Limited?

2) How does the lending, monitoring and intervention process aid Adansi Rural Bank to recover overdue credit?

3) What are the challenges encountered by Adansi Rural Bank Limited in credit risk management?

\subsubsection{Significance of the Study}

The banking industry in Ghana has witnessed the failure of many rural banks and this has mainly been as a result of inefficient credit risk management practices. This research may help rural banks in Ghana to improve on the quality of their credit risk management practices and policies. The study identifies the types of credit risk rural banks are exposed to and provides appropriate measures to mitigate the credit risk. This study will provide adequate information to the regulatory bodies on the challenges rural banks are exposed to when dealing with credit risk in Ghana.

This information will assist in improving existing policies which can eventually improve the entire performance of the industry in the long term. This study will give the Government a form of intuition into the objective of strengthening financial services. This needful information will put the Government in a position where it will be able to know which policies should be improved to ensure the smooth running of rural banks in the country. This study will also provide essential information to individuals who will want to borrow from rural banks. Finally, it may serve as a benchmark for researchers to conduct further studies in this area.

\subsection{The Scope of the Study}

This study broadly focuses on credit risk management practices of rural banks in Ghana but limited to Adansi Rural Bank Limited. The study will be restricted to the staff of the bank. This bank was used because it is one of the leading rural banks in Ghana. Adansi Rural Bank has highly competitive banking products. Among which are; commercial loans, salary loans, overdrafts, transport loans, group loans and agricultural loans.

\subsubsection{Limitations of the Study}

The researcher encountered many problems in the course of the study. Notable among them was the duration of the study. The duration given to complete the study did not allow a comprehensive and thorough investigation into the study. Inadequate funds made it burdensome for the researcher to access all available data as it limited the extent to which the researcher was able to gather data. Also, the study was limited to Adansi Rural Bank Limited so the findings and recommendations do not represent all rural banks in Ghana.

\subsubsection{Organization of the Study}

The study is arranged systematically in five major chapters. Chapter one deals with the background of the Study, problem statement, research objectives and questions, significance of the study, the scope and organization of the study. Chapter two deals with a review of literature on what other researchers and authorities on the subject have written. Chapter three deals with the methodology and the profile of Adansi Rural Bank Limited. Chapter four presents the analysis, findings, and discussions of the data collected. Chapter five deals with the summary of major findings, conclusion, recommendation and implications of the finding.

\section{Literature Review}

The chapter reviews the theoretical studies with the aim of accomplishing the different hypotheses of credit risk procedures. This will be followed by the empirical review of literature. The theoretical literature highlights the various theories of credit risk management. The theoretical review throws more light on the definition of credit risk management, what is credit, sources of credit risk, evolution of credit risk management and credit risk management practices. Again there are other theoretical dimensions like credit risk management programme, credit risk measurement and the effect of non-performing loans on the performance of a bank. The final part of 
this chapter examined some relevant empirical reviews on the different credit hazard administration, the credit procedure and loan advances and its impacts on the performance of banks execution.

\subsection{Overview of Credit Risk}

Credit risk is an investor's risk of loss arising from a borrower who does not make payment as promised (Bluhn, etal., 2002). Credit is an arrangement by which a buyer can take possession of something now and pay for it later or over time (Encarta, 2009). Credit is the trust which allows one party to provide resources to another party where that second party does not reimburse the first party immediately, but instead arranges either to repay or return those resources at a later date (Sullivan et al.,2003). The re-payment of the resources is arranged by the lender and borrower. The resources are not limited to financial resources. Resources can take the form of goods and services.

Credit risk is defined as the risk that the expected returns from the credits given and securities held by the credit unions may not be repaid in full (Garr, 2013). Credit risk is also the doubt that a borrower will repay what is given to him or her. This is the risk that the counter party will not be able to repay the credit received. Credit risk is considered to be the risk to income and this is as a result of credit defaulters. Credit risk encompasses transaction risk and portfolio risk. Whiles transaction risk is the risk associated with individual credits, portfolio risk is the risk associated with the total credits in the portfolio. Credit risk primarily consists of two components. Credit risk is the combination of default risk and exposure risk (Singh, 2013).

\subsubsection{Characteristics of Credit Risk}

The Edinburg school of thought proposed relevant characteristics of credit risk. There are three characteristics that define credit risk;

- Exposure (to a party that may possibly default or suffer an adverse change in its ability to perform).

- The likelihood that this party will default on its obligations (the default probability).

- The recovery rate (that is, how much can be retrieved if a default takes place).

- The larger the first two elements, the greater the exposure to risk. On the other hand, the higher the amount that can be recovered, the lower the risk. Formally, we can express the risk as: Credit risk $=$ Exposure * Probability of default * 1-Recovery rate.

\subsubsection{Sources of Credit Risk}

The following are some of the causes of credit problems in banks and financial institutions; credit risk shows pitfalls in the process of credit granting and monitoring. There are shortcomings in underwriting and managing market-related credit exposures. This is a source of loss to banks. Problems associated with credit can be mitigated if efficient internal credit processes are employed (Basel Committee on Banking Supervision, 2000)

Again credit risk may arise from subjective decisions made by senior management of the bank. Credit risk may arise when credit is extended to friends who do not qualify to access credit, with the aim of meeting a personal agenda. In the early 1990s many banks failed to monitor borrowers or collateral values. This was a common characteristic of many troubled banks during that time. The banks did not monitor periodic financial information of debtors.

If they had monitored their debtors they could have evaluated the quality of loans and collateral on their books. As a result, many banks failed to recognise early signs associated with the deterioration of the quality of an asset. There by missing the opportunity to curb the deteriorating asset.

Underwriting problems usually reflect the absence of thoughtful consideration of downside a situation. Borrowers can be vulnerable to changes in risk factors like changes in commodity prices, shifts in the competitive landscape and the uncertainty associated with the success of a management direction. Usually lenders fail to "stress test" or analyse credit using sufficiently adverse assumptions so in the end they fail to detect vulnerabilities.

Market risk exposures present gruelling challenges that banks experience during the credit processes. Foreign exchange risk is an example of market-sensitive exposures banks experience. The nature of financial contracts requires that banks should have the requisite to assess the probability distribution of the actual size of the exposure in the future and the impact it can have on the debtor and the bank.

\subsubsection{Overview of Credit Risk Management}

Credit risk management is a management tool that helps to maximize a bank's risk-adjusted rate of return by maintaining credit risk exposure within acceptable parameters (Casu et al., 2006). Casu et al explained that "the 
need for financial institutions like banks to manage credit risk arising from individual creditors, individual transactions and the risk inherent in their entire portfolio is very critical to their success and survival". The essential function of credit risk management is to "identify, measure, and more importantly monitor the profile of the bank" (Raghavan, 2003). Based on this definition, credit risk management helps financial institutions to examine, monitor and evaluate the various activities in order to mitigate credit risk. Raghavan also describes risk management as a system which is "a proactive action in the present for the future".

Again, Kalapodas et al. (2005) describes credit risk management as a management tool which attempts to eradicate, reduce and manage risks, increase the benefits and avoid harm from taking risks. In effect credit risk management prevents financial institutions from credit risk and enables them to improve in terms of financial performance. Also, credit risk management is described by Gestel et al. (2009) as primarily concerned with reducing earnings volatility and avoiding large losses in a firm. In a rigorous risk management process, a bank should identify the risk, quantify the risk by measuring it and develop measures to manage the risk effectively.

The Eastern Caribbean Central Bank Report (May 2009) also stated that "the objective of credit risk management is to maximize a financial institution's risk adjusted rate of return by maintaining credit risk exposure within acceptable parameters". The report showed that credit risk management should not only effectively address the credit risk inherent in the credit portfolio but it should also consider the relationship between credit risk and other related risks. Again, the effective management of credit risk is an ineluctable component of a comprehensive approach to integral risk management and is indispensable to the safety and soundness of a financial institution. Suitable policies and systems should be implemented in financial institution so that there will be effective, identification, measurement, monitoring and credit risk mitigation.

\subsubsection{Evolution of Credit Risk Management}

The origin of credit risk can be traced back thousands of years (Brown, 2004). To this researcher, credit is older than even writing. Hammurabi's Code codified legal thinking about four thousand years ago in Mesopotamia, but this code failed to outline the basic rules for borrowing. Hammurabi's code also failed to define the fundamental rules for dealing with default, collateral and interest (Brown, 2004). However, this code underscores failure to pay a debt as a crime that should be treated as a swindle or even a robbery. The code is renowned for arguing that the Bible has records of enslavement as a result of unpaid debt. The account of Elisha and the widow's oil shows the threatened enslavement of two children because their father died without paying his debts. The Bible also goes further than Hammurabi in limiting the collection rights of creditors-purely as a matter of mercy. The modern bankruptcy concept which offers protection to creditors cannot be found in the Bible and Hammurabi Code. In the prehistoric times, credit default was considered to be an unpardonable misconduct which was punishable by death.

Credit risk is a necessary consequence of a vigorous economy. Every party involved in a complex production processes will have to wait for goods or services to be delivered to the final consumer before receiving payment. When there is a failure in the process, the loss must be allocated to producers or investors.

These intermediaries can reduce the amount of risk by employing fractional reserves to aid diversification. However, the delays in the payment of credit may lead to credit risk exposures. "In the 18th century, Lewis Tappan founded the Mercantile Agency which became Dun \& Bradstreet.

This company provided commercial information on businesses throughout the United States". This time witnessed the advent of specialized financial press. The firm merged with Standard Statistics which later became Standard \& Poor's. In 1916 Standard \& Poor's had its official credit ratings (Brown, 2004). Between 1953 and 1960 W. Braddock Hickman's three volume study of US corporate bonds was his first attempt at quantification. All his facts about finance were wrongly concluded and this was attributed to his knowledge in economics

In addition, Brown (2004) argues that, as older practitioners took Hickman's wrong turn, the field of credit risk management opened up to young innovators and during the period of 1965 to 1975, people under the age of thirty were interested in credit risk management and performed jobs relating to credit risk.

\subsubsection{Credit Risk Management Programme}

In the report published by Eastern Caribbean Central Bank (2009), it stated that to achieve and maintain effective credit risk management, a financial institution should develop and implement a comprehensive credit risk management programme in accordance with its credit risk strategy. The credit risk strategy should reflect the institution's tolerance for risk and the desired level of profitability for incurring various credit risks. The board of directors, management and staff of the financial institution should fully understand their shared responsibilities within the credit risk management programme. 
An identifying feature of an effective credit risk management programme is the implementation of clearly defined credit policy and processes to facilitate the identification and quantification of risks inherent in an institution's lending and investment activities. The following sub-sections are highlights of what was considered as comprehensive credit risk management programme in the report.

\subsection{Credit Policy}

The credit policy establishes the authority, rules and framework for the effective operation and administration of the credit portfolio. The policy should be communicated throughout the entire organization in a timely manner. The credit policy should be implemented effectively through the use of appropriate procedures. It is necessary for the policy to be reviewed annually. This will ensure that the policy remains effective and flexible, and continues to meet the institution's objectives. Changes in statutory and regulatory requirements should also be incorporated in the policy.

A comprehensive credit policy that is effectively implemented will enable a financial institution to maintain sound credit-underwriting standards; assess, monitor and control credit risk. A comprehensive credit policy can properly evaluate new business opportunities, identify risk, administer and collect problem credits.

\subsubsection{Credit Risk Management Processes}

The credit risk management process in the Eastern Caribbean Central Bank report (2009) included credit appraisal and credit approval. Credit appraisal is a point in the credit risk management process where all required information on the credit is gathered and credit applicants are assessed. Credit application forms should provide all relevant details so that adequate information can be gathered for credit assessment. In light of this, it is precautionary for financial institutions to have a checklist to ensure that all required information is collected. The criteria for appraising corporate credit applicants will differ from the criteria for appraising personal credit applicants. Insider loans should be appraised objectively.

\subsubsection{Measuring and Monitoring of Credit Risk}

The report of Eastern Caribbean Central Bank (2009) further stated that financial institutions should have comprehensive procedures and information systems to effectively monitor and control credit risk. These procedures should incorporate prudent measures for identifying problems, reporting existing problems and accounts with potential problems, thereby ensuring that such accounts are reviewed, adequately monitored and the necessary rectifications are made. The effectiveness of the credit risk management framework depends largely on the adequacy of management information systems.

Financial institutions should have information systems and analytical techniques that have imbedded flexibility to aid in the identification of:

- Risk concentrations, such as, credit grouped by related borrowers, economic sector, geographic areas and so forth;

- Volumes of loans secured versus unsecured;

- Volumes of new loans generated by officers;

- Missing or inadequate information such as financial statements;

- Restructured debts, expired and written-off accounts.

Financial institutions should have in place a credit rating system that defines risk rating criteria and rates credits according to these criteria. Financial institutions should have appropriate criteria for classifying credits, recognizing revenue and providing coverage for loan loss.

Institutions should have a well-defined credit collection and arrears management process. For institutions that have a high level of nonperforming loans, it is recommended that a unit should be set-up to handle the recovery of nonperforming loans.

\subsubsection{Adequate Credit Risk Controls}

\section{Segregation of Duties:}

Financial institutions should create internal controls that will ensure that credit initiation, approval, review, administration, payments and work-out functions are kept as separate as possible. Breaches of internal controls and practices should be reported to the appropriate level of management. (Eastern Caribbean Central Bank report, 2009).

Credit Review: 
Financial institutions should establish an independent system with an ongoing assessment of its credit risk management processes and the results of the reviews should be communicated directly to the appropriate unit. The credit risk management programme of each institution should include procedures governing the formal review and rating of individual credits. An independent review of credits should be conducted along with regular analysis and rating of credits by account officers. Because of their frequent contact with borrowers, account officers are in a position to detect changes in a borrower's operations or financial condition.

Basel committee on Banking Supervision elaborates on the basic principles for the assessment of a bank's management of credit risk. One of the principles is establishing an appropriate credit risk environment where management will have the responsibility of approving and periodically reviewing the credit risk strategy. Through this measure, credit risk policies of a bank, should be able to identify and manage credit risk inherent in all products and services. Operating under a sound credit granting process is the second principle.

This is where banks operate under a sound, well-defined credit-granting criterion. This criterion gives a thorough assessment of the borrower, the purpose, structure of the credit as well as the source of repayment (Basel Committee on Banking Supervision, 1999). Basel II Accord identifies effective credit risk management as an essential component of a bank's overall risk management strategy.

\subsubsection{The Role of Supervisors in Credit Management}

The Basel Committee (2000) advised that supervisors should ensure that a bank has an effective system that can identify measure, monitor and control credit risk as part of an overall approach to risk management. The Basel Committee (2000) stated that supervisors should conduct an independent evaluation of a bank's strategies, policies, procedures and practices relating to the granting of credit. The Basel Committee (2000) added that supervisors should consider setting limits to control the exposures of the bank.

The Basel Committee gave a directive that the Board of Directors should approve and periodically review credit risk strategy whilst senior management should ensure its effective implementation. Although this directive may not be stated in the policies of rural banks, it is implemented and practiced by many universal banks. A sound credit risk management process serves as the fundamental tool for assessing the credit worthiness of borrowers.

This measure ensures that credit assessed is used for its intended purpose. High-risk projects should be monitored regularly to ensure that the assessed credit is used for the intended purpose. The Bank of Ghana in its recent publication requested all banks to nominate risk officers to coordinate the various measures instituted to control risk exposures of banks. In the case of rural banks, credit limits have been set by the Bank of Ghana, beyond which such facilities should be submitted for ratification before disbursements are made. The effective implementation of these measures can aid financial institutions in achieving appreciable financial performance.

\subsubsection{Determining Borrowers Credit Worthiness}

Before lenders decide whether to grant credit or a loan, they evaluate a potential borrower's credit worthiness or the borrower's ability to pay back the credit (Okyere, 2014). In the credit evaluation process, lenders consider the following:

\subsection{Character}

This refers to the borrower's integrity and willingness to repay the financial obligation as well as his or her reliability and trustworthiness. Answers to questions such as the following help a lender determine a borrower's character when applying for a personal loan:

- Do you pay your bills on time?

- Have you used credit before?

- How long have you lived at your current address?

- Where do you work, and how long have you held your present job?

- Are you married?

Character will is a factor that will be considered when a business entity applies for a loan. A company that wants to access credit should have a good reputation.

\subsubsection{Capacity}

This assesses the borrower's cash flow and the ability of the borrower to repay the debt. There is risk associated with every business transaction; it is no doubt that uncertainties will be realized in the future. In light of this, borrowed fund should generate sufficient funds during the duration of the loan to cover these contingencies. It is 
precautionary not to grant credit to a borrower with a fitful income. On the other hand, a borrower who receives a high regular income but has many debt obligations should not be allowed to access credit.

\subsubsection{Capital}

Capital is considered to be the borrower's financial net worth. A remarkable net worth can offset insufficient cash flows. Lenders consider a borrower with an enormous net worth as having a reliable credit source to repay the loan. The value of a borrower's capital gives a lender a well grounded evidence of whether the borrower will default in the loan repayment or not. In the assessment of a borrower's capital, the lender can ask questions similar to this: "What property does the borrower have that can be sold to generate credit within a short period of time to repay the debt?" This can be stocks, bonds or real estate holdings.

\subsubsection{Collateral}

This refers to any property owned by the borrower that can be pledged for security. If the property has been previously pledged against another loan, financiers would probably not consider it available to be pledged again until the previous loan has been paid off (Okyere, 2014).

\subsubsection{Conditions}

These refer to economic, industrial and company-specific prospects and events that may occur during the period of the loan that could have a significant effect on your company. These might include rising raw material prices, an employee strike, increasing interest rates, etc. (Okyere, 2014).

\subsubsection{Inventories}

Lenders will examine the company's inventories. It is precautionary not to assume that large inventory can be considered as collateral that can be readily pledged against a loan. Lenders examine the speed with which a borrower's inventory is rotated. A faster inventory rotation is the best choice for the lender. A borrower with inventory for the next year, is negatively impacting cash flow. This condition indicates that the borrower's products have poor patronage. However, if you are "turning" your inventories every month, your financiers should be very happy. (Okyere, 2014).

\subsubsection{Receivables}

How well are you doing at collecting your debts? If you give your customers 30-day terms, are they paying on time? In a situation where the receivables of a borrower are averaging 60 days, it will cost the borrower both money and the confidence of the lenders.

\subsection{Credit Appraisal Techniques}

The guidelines for rural banks in Ghana indicate that, rural banks should operate within a sound and well-defined criteria. Rural banks should extend credit to their target markets. The lender should make an assessment of the risk exposure of the borrower.

The appraisal techniques include:

* Assessment of the macro-economic variables.

* Assessment of the purpose of credit and source of repayment.

* Examination of the repayment history or reputation of borrower.

- Evaluation of the repayment capacity of the borrower.

* Examination of the restrictive covenants.

* Evaluation of the adequacy and enforceability of collaterals.

* Approval from appropriate authority.

Stigliz (1990) also avows that group members have better access to information on reputation, creditworthiness and an intended purpose of peer borrowers than the bank official. Lenders are not able to access all relevant information of potential borrowers, so it is extremely difficult to distinguish 'good' borrowers from 'bad' borrowers as argued by Fraser (2004).

According to Ahmad (2001) there is no procedure for ensuring that loans do not go bad, as there are uncertainties that can go against even reputable borrowers. Ahmed (2001) suggested the general procedure for reviewing short term lending proposals in the following areas; Company Profile, Purpose of facility: Source of repayment, Security, Financial Analysis, Management Evaluation, Risk Areas, Checking, Loan Profitability. Credit analysis is the process of deciding whether to extend credit to a given customer or not (Maness, 2011). Maness (2011) 
again outlined certain individual traits that must be used for this analysis, which he referred to as the 5Cs, namely, the customer character, capacity to pay, collateral to support the loan, capital or asset-base of the customer, and the general economic condition under which the customer operates. Andrews (2004) believes that credit analysis includes financial and non-financial factors, and these factors are all interrelated.

These factors include the environment, the industry, competitive position, financial risks, management risks, loan structure and documentation. Where formal financial institutions rely on quantitative data such as credit histories in order to assess and mitigate risk, micro finance institutions have found that the reliance on trust can result in extremely low default rates; in fact, a micro finance institution that is managed well will typically be exposed to a default rate of below $3 \%$. The poor rarely have formal credit histories, and are unable or unlikely to be able to offer anything of value as collateral to secure a loan (Kereta, 2007).

\subsubsection{Credit Risk Measurement}

The ability of banks to measure credit risk effectively has the potential to improve the risk management capabilities of the bank. With the forecasted credit loss distribution in hand, the user can decide how best to manage the credit risk in a portfolio, such as by setting aside the appropriate loan loss reserves or by selling loans to reduce risk. To a larger extent the use of credit risk models will enable the banks to undertake portfolio management, which takes due account of the varying impact of business cycles on lending (Andersen J. et al., 2000). The models will make it possible to assess risk and earnings. This will ensure that an appropriate tradeoff between yield and the risk assumed by the bank.

It is important to note, however, that in the process of banks to make decisions to grant credit they will continue to depend on an assessment of the actual risk with an exposure details. As in traditional credit assessment, the basis for a credit model is to determine the risk and earnings on each credit exposure. However, in a credit model it is not sufficient to estimate earnings and risk on the basis of qualitative groupings. On the contrary, exact measures must be set for each individual exposure. As in the case of risk assessment of each credit exposure, the use of a credit model implies that the correlation can be quantified in terms of exact correlation data. It is thus not enough merely to have a general overview of the correlations between the various types of loans. Instead, there must be an exact statistical measure of the links to all other types of loans in the credit portfolio.

There are many types of credit risk measurement tools but this research will be limited to commercial credit tool. The main variables affecting the credit risk of a financial asset are the probability of default (PD), the loss-given default (LGD), and the exposure at default (EAD) (Baixauli \& Alvarez, 2009).

\subsubsection{Procedures Involved in Lending}

Fraser and Korari (2007) maintain that failure is normally the result of reckless lending, lack of diversification or even both. Hempel, Simonson and Coleman (2012) share the same view but they further explain that effective organisation and control of the lending function is vital to the profitability of a bank. Rose and Conrail (2008) recommend the formulation and implementation of a sound lending policy. In their view these are the most important responsibilities of the leadership of a bank. They suggested that before a financial institution establishes a loan policy, the institution should address how loan applications are evaluated.

\subsubsection{Loan Policy}

Rose and Korari (2010) outlined the following components that should be a part of a loan policy:

- Objectives: This refers to loan examination which is carried out by directors of the rural bank with the aim of assessing the impact of the bank on the community's economic growth.

- Trade Areas: The primary and secondary areas should be designed to inform loan officers of the bank's geographical boundaries. According to Crosse and Hampel (2008), the bank should define its geographical boundaries.

- Loan Mix: The bank should have clear policies on the collection of loans it intends to hold in its portfolio within a specified period. The demand of the local economy, the size of the bank and the expertise of its management should have an impact on the type of specified loan mix. (Rose \& Korari, 2006).

- Loan Pricing: The rate charged for risk exposures of a loan varies. It is possible to group the loans into an identical risk category (Rose \& Korari, 2006).

- Credit Standard: A Loan policy should indicate the type of collateral the bank prefers. The loan policy should show situations in which an unsecured lending is prohibited. The quality and liquidity of collateral must be verified and maximum loan collateral value ration should be applied before a secured loan is approved. (Hempel, Simonson, \& Coleman, 2012). 
- Loan Authorisation and approval: The policy should establish lending for all loan officers and for a combination of officers and loan committees (Hempel, Simonson, \& Coleman, 2012).

\subsubsection{Bank Lending Behaviours and Determinants of Credit Risk}

Financing involves risk which has to be managed by the rural bank. The management of risk centres on determining the type of risk exposure that exist in an investment and handling these risks in a way best suited to the financing or investment objectives (Mwime, 2001). The management of credit risk should be guided by a regulatory frame work. Some bank lending behaviours and its determinants of credit risks are:

\subsubsection{Deposits}

Deposit is money paid to the bank. Deposits determine the ability of a bank to extend credit to borrowers. In a study Goldstein et al. (2004) discovered two types of deposits made by customers. The deposits are categorized as compulsory and voluntary savings. Compulsory deposits require clients to deposit a specified amount of money within a specified period. Goldstein et al. (2004) explained that compulsory deposit is associated with credit disbursement and can either be preliminary savings for a loan or collateral savings. A customer who has an intention to collect a loan usually undertakes preliminary savings. The deposit the borrower makes within a specified period is used as a measure to determine the credit worthiness of the customer. Voluntary savings on the other hand requires that the customer saves any amount of money at his or her convenient time interval. This can be accessed by the customer at any time. Otero and Rhyne (2011) revealed that the poor and low income earners prefer flexible (voluntary) savings. Goldstein et al. (2004) explain that voluntary savings are categorized in two major forms namely cash deposit and time deposit.

Customers prefer the use of cash deposits. The use of cash deposit allows customers to open an account and make deposits based on their financial strength. Customers who prefer the use of cash deposits can access their account at anytime (Goldstein et al., 2004). On the other hand a time deposit requires that customers make a large sum of savings for a specified period of time. There is a positive relationship between the lending characteristics of a bank and the deposits of a bank. The bank will be able to grant more loans to customers as the bank receives more deposits from its customers. This increases the loan default rate of customers. Obviously the ability of a bank to grant a loan to customer is not solely dependent on deposits collected by the bank. It is partly dependent on the interest paid on the deposit by the bank. The "deposits ratio is measured as the ratio of customer deposits to total bank liabilities" (Abdul et al., 2014).

\subsection{Equity Ratio}

Banks with large capital cushion will be able to extend credit to customers over a longer term as compared to banks with little capital cushion. Banks with little capital cushion can only afford to extend short term loans to their customers as this is a precautionary measure to keep the bank solvent. Consequently, increasing bank equity improves the capacity of a bank to raise lending (Abdul et al., 2014).The capitalization of a bank can determine whether the bank can extend a long term or a short term credit facility.

The ratio of a bank's book equity to asset can determine the capitalization of the bank. Bouvatier and Lepetit (2007), and also, Djiogap and Ngomsi (2012) "find that poorly capitalized banks are restricted to increase credit". Banks that are properly capitalized have the capacity to attract credit worthy customers.

\subsubsection{Determinants of Credit Risk in Rural}

At the macro-economic level, non-performing facilities, loan concentration as well as bank size are important determinants. Al-Smadi and Ahmad (2009) indicated "that an in-depth work and understanding on the manner in which internal and external factors contribute to credit risk warrant further analysis". The efficiency of management is a major determinant of credit risk in banks. Highly skilled management of a bank will presumable have a better anticipation of the loan market. Highly trained credit officers have a lower probability of granting credit to defaulters. There have been many reported bankruptcy cases in Kenya where banks like Continental Bank, Trade Bank and Pan African Bank have all engaged in extensive poorly analysed lending process. Credit evaluation, supervision, and monitoring and approval play a big role in determining the repayment ability of the borrower (Ibrahim et al., 2014).The largest cause of bankruptcy of rural banks is attributed to poor lending practices of management. In more than half of the failed bank cases, poor assessment of loan applicants and quick approval of loans to customers who are not credit worthy was the leading cause of rural bank failures. Other factors such as poor credit administration and inefficient internal control systems are key internal determinants of credit risk. 


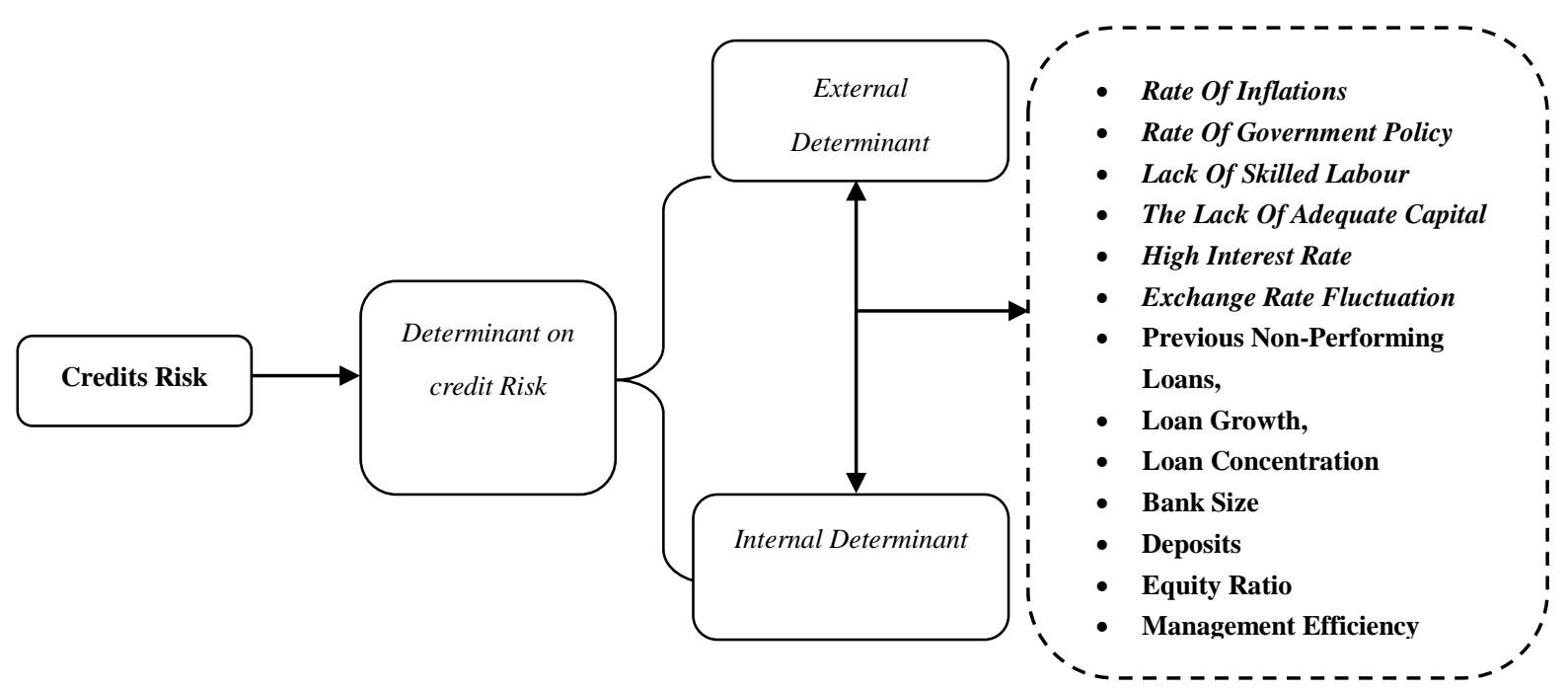

Figure 1. Conceptual model for determinants of credit risk

\subsubsection{Macroeconomic Determinants of Credit Risk in Rural Banks}

There are many economic factors that can increase credit risk in rural banks in Ghana. Global economic pressures regularly trickle down to the Ghanaian economy. A global economic down turn will definitely impose negative repercussions on the local economy. This shows that the economic condition of a country has influence on the ability of borrowers to pay back assessed credit. Park (2012) argues that the reduction in prices in the 1980 s created a downward slope in the economic growth of oil producing countries.

This outcome had a negative effect on household expenditure, corporate expenditure and government expenditure. The impact of the global pressure was so severe to the extent that financial institutions, governments and individuals were unable to settle their debt obligations. Park (2012) therefore summarized the effect of adverse economic conditions by reporting that adverse economic condition leads to high government fiscal deficits, low rate of economic growth, high inflation, heavy corporate and individual debt and high rate of banks' credit risk.

During economic downturns, banks adapt to the changed economic condition by devising severe credit policies, which have tendencies of denying many customers the opportunity to assess credit. While carrying out this task, banks devise an alternative measure to increase total savings mobilised. Some of these devices end up deceiving customers, which in the long term give the bank a bad reputation (Naceur \&Omran, 2011).

According to $\mathrm{Pu}$ and Zhao (2012) "there is a positive relationship between credit risk and favourable macroeconomic condition of a country". A significant growth in the economy is likely to increase the loan repayment rate. Festic et al.(2011) argues that "changes in the macroeconomic environment translate into changes in the quality of a loan portfolio in banks". During an economic recession, loan default rate increases.

\subsubsection{Inflation}

Inflation is considered to be one of the economic variables that determine credit risk in lending. Inflation refers to the continuous rising of prices of goods and services in an economy within a specified period of time. Thiagarajan et al (2011) is of the view "that there is a positive relationship between inflation and credit risk of banks". Inflation has an impact on both lenders and borrowers. Farhan, Sattar, Chaudhry and Khalil (2012) argue that when inflation is high and businesses lose their profit, the possibility of repaying loan is low thereby leading to loan default. high inflation decreases the purchasing power of the credit assessed by borrowers. Inflation increases the cost of borrowing. The effects of inflation on the profitability of banks depend on the rate at which the banks operational expense increases (Athanasoglou et al., 2008).

\subsubsection{Central Bank Policy}

Capital requirement is one of the policies employed by the Bank of Ghana. The central bank ensures that rural banks maintain a required minimum ratio of client deposits and notes. Navneet et al. (2009) explains that increases in non-interest bearing reserve requirement results in a widening of banking spread as banks face decreased liquidity. Kwakye (2010) argues that "the fact that the reserves are unremunerated costs to the banks, as they have to pay interests to deposit customers, however low that may be". Raising reserve requirement 
compels rural banks to withhold a greater proportion of their funds resulting in the reduction of the money supply in the economy.

The reserve conditions set the minimum capital reserves that rural bank should hold to demand deposits and bank notes. The reserve conditions in the rural banks, controls credit supply. Sarpong et al.(2011) is of the view that "in Ghana, commercial banks respond to increases in reserve requirements by increasing the margin between lending and deposit rates".

\subsubsection{Monetary Policy of the Central Bank}

Money supply has also been considered by scholars such as Ahmad (2009) and Berk and Bikker (2010) as a determinant of credit risk in rural banks. According to Berk and Bikker (2010) any attempt by the central bank to increase or decrease the supply of money in the economy will have an impact on credit risk. Berk and Bikker (2010) reported that any time the economy experiences an expansion in the monetary supply, productivity increases and individuals and corporations experience an increase in their respective incomes. Ahmad (2009) carried out a research in Malaysia which was aimed at examining the key factors that affect risk exposure of banks. Ahmad (2009) found in his study "that there exists a significant relationship between money supply and credit risk".

The researcher pointed out that an increase in money supply leads to a proportional increase in the productivity and profitability of borrowers there by reducing the loan default rate of borrowers. On the contrary, Sarpong et al. (2011) reported that the influence of money supply on credit risk affect lenders negatively. According to Sarpong et al. (2011), "money supply is the total amount of money inflow in the economy". If so much money is supplied in the economy, it indirectly increases inflation. This indicates that money supply has an impact on inflation and credit risk as discussed earlier. There is clear evidence that money supply is a determinant of credit risk in rural banks in Ghana.

\subsection{Interest Rate}

Interest rate can be viewed from two perspectives. From the borrower's perspective, interest rate is the cost of borrowing but from the perspective of the lender, interest rate is the compensation received from differing consumption of credit to a later date in the future. Abreu and Mendes (2000) and Ameyaw (2010) have stated that interest rate is a major source of finance to banks. Abreu and Mendes (2000) also conducted a research on the performance of rural banks. The findings of their research showed that, interest rates paid by customers on credit they have assessed serve as a major contributor to the profits banks make. However, Abreu and Mendes (2000) stated that rural banks experience a reduction in their projected profits when credit facilities are extended to borrowers without effective credit appraisal techniques. A higher interest rate is an indication that cost of borrowing is high. This usually discourages borrowers from borrowing. However, in cases where credit was extended to borrowers at high interest rates, higher loan default rates have been the resulting outcome. Jiménez and Saurina (2006) conducted a research with the objective of assessing the influence of interest rates on the credit risk of banks. The duo found out that interest rate has a positive impact on credit risk exposures of banks. "The same relationship was displayed between the interest rates and credit risk as was experienced in the ten year Italian Treasury bond and the loan loss provision" (Quagliariello, 2007). The historical evidence points out clearly that high interest rates increase the debt obligations of borrowers. This agrees to the fact that, "High interest rate is a determinant of credit risk".

\subsubsection{Exchange Rate}

Exchange rate refers to the price of one currency expressed in another currency. The gains or losses a local currency makes against major foreign currencies have an impact on credit risk. Exchange rate policycan have an effect on the economic activities in a country which can affect both negative and positive on businesses. When a local currency depreciates against a foreign currency, import becomes expensive which eventually affects the prices of import goods. To the entrepreneur, an increase in capital would be the only way to continue in business and for that matter loan would be the appropriate option. Meanwhile, the continuous increase in the prices of goods and services can increase inflation.

Inflation will decrease the purchasing power of buyers and this will lead to a reduction in the sales of goods and services. Vogiazas and Nikolaidou (2011) conducted a research which was aimed at establishing real effective exchange rates on the performances of commercial banks in Bulgaria from 2001 to 2010. In their findings, they pointed out that "as the domestic price of foreign exchange rate rises (depreciated) it becomes more expensive to procure foreign product and services as their cost would have increased thereby requiring more units of domestic currency to acquire the same quantity of foreign goods and services than before". 


\subsubsection{Trends of Credit Risk in Rural Banks}

A vibrant banking industry is usually supported by practical policies. Aduda and Gitonga (2011) explained that "credit risk management has influence on profitability at a reasonable level". Kithinji (2010) stated that "the larger proportion of a bank's profit was influenced by other variables other than credit and nonperforming loans".

Nair and Fissha (2010) in their work reveal that "the proportion of loan portfolio that was in default (among the sample of twelve banks) for more than one month was $16 \%$ ". This was too high and quite intolerable given the world-wide average of $3 \%$ for the global micro-banking industry. They also pointed out in a similar work of the Ghanaian rural banking industry "that, the degree of loan delinquencies or impaired loans in rural bank's loan portfolio is often taken as the best leading indicator of the institutions' financial performance".

Hosna et al. (2009) noted that nonperforming loans have an enormous effect on profitability as measured by Return on Equity (ROE) more than capital adequacy ratio, and its effect on credit risk management on profitability was not the same for all the banks included in their work. Ogboi and Unuafe (2013) explained that the financial performance of banks have been influenced by effective management of credit risk and capital adequacy. Moreover, Abiola and Olausi (2014) reveal that profitability of banks has been influenced by credit risk management.

Abdelrahim (2013) conclude that liquidity and the size of a bank have a strong effect on potency of credit risk management. Berrios (2013) indicated that "less discreet lending negatively affected net interest margins". Kaaya and Pastory (2013) pointed out that "credit risk indicators negatively affect bank performance". Adeusi et al (2013) stated that "risk management indicators, such as doubtful loans, and capital asset ratio affect the performance of banks".

\subsubsection{Ghana's Financial System and Credit Risk}

According to Apanga et al. (2016), "credit risk practices within listed banks in Ghana are in line with sound practices. The only dissimilarity, however, is the role of the board of directors in defining acceptable types of loans and maximum maturities for the various types of loans. Listed banks in Ghana are also exposed to credit risk associated with granting both corporate and small business commercial loans and the use of collaterals to mitigate their credit risk exposures".

Allen et al. (2006) elucidated that the banking industry experienced major setbacks because credit resolutions lacked profitable attentions and also had limited innovation and appropriate governance structures. An overview by Ackah and Asiamah (2014) show that the banking stratum in Ghana was controlled by state owned banks with official apportionment and credit pricing in the 1990s and this led to the uncompetitive and inefficient intermediation process of the banking system. With regards to Ghana's banking industry, lending has become the main portfolio of banks but factors such as interest rate, inflation, central banks regulations and reserves etc., has become key element which raise the red flag on risk in giving out credit to Borrowers.

\subsubsection{General Credit Monitoring}

Monitoring of credit facilities granted to customers is a significant function in ensuring the success of the project for which repayment is made. Huppi and Feder (1990) revealed that effective monitoring leads to higher recovery of loans by exposing possible dangers like loan diversions and reminding borrowers of their obligations to the lending bank (i.e. calling for redoubling of efforts towards loan repayments). Monitoring of credit facilities has been concentrated typically on ensuring repayment when there are signs of defaults for either payment of interest or principal repayment by installment. Such practice, in the view of the researcher, fails to achieve desirable loan repayments since the facility might have already gone bad.

The researcher believes that monitoring of loans should be carried out by following events right from the disbursement of the facility, ascertaining the deployment of funds on the intended project, following up and reviewing progress of the project, identifying shortcomings for possible advice through field visits and discussions, ensuring prompt repayment of proceeds from the project and advising on further expansion or re-direction of the project among others. "Arm-chair" monitoring invariably becomes a factor for non-repayment of credit facilities. Effective monitoring should be instituted by a lending institution and apprise management of the state of affairs of each project.

\subsubsection{Some Control Risk Tools useful in the Lending Process}

Tools that have been considered useful in the lending process which helped to control losses are loan securitization, covenants, credit rationing, collateral and loan syndication Hugh (2001). In as much as these tools 
help control and reduce credit risk, they also serve as interventions to recover overdue credit. From his view, once these tools are adopted, a measure of success is guaranteed. Marphatia and Tiwari (2004) contrasted the view above by laying emphasis on the fact that, managing risk is basically human interaction, therefore having well trained and qualified staff in the area of risk management is rather key in controlling the latter. Their point was, technology is only an instrument and will be futile when in the wrong hands but knowledgeable well trained staff won't necessarily embrace unbending strategies yet even their connection and the trust they build with clients will minimize if not thoroughly take out risk of default. Figure below illustrates some tools.

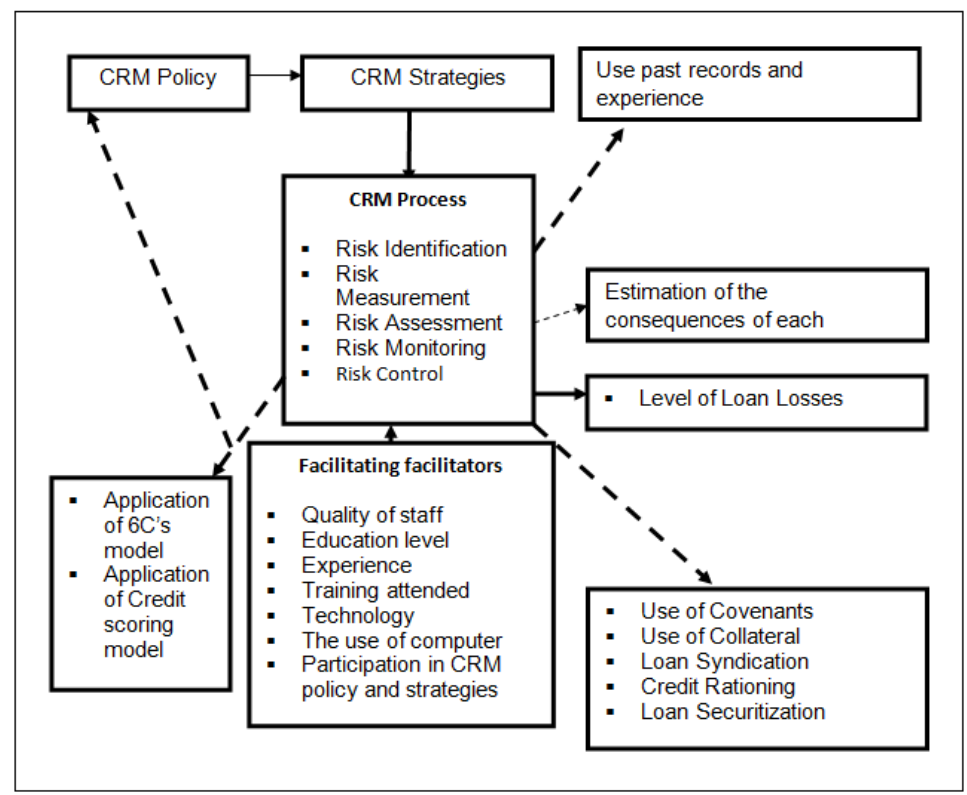

Figure 2. A comprehensive model for the credit risk management system of a commercial bank

\section{Introduction}

\subsection{Methodology and Organizational Profile}

This chapter concentrates on the discussions on the description of the research design, sampling techniques, data collection methods, research procedures, data analysis, ethical considerations, the organizational profile and how the results will be presented. The methodology of the research shows the procedures that have been taken in conducting the research.

\subsubsection{Research Design}

The research design of the study provides a framework for collecting and analyzing data. It shows how the research questions in chapter one would be answered and the sources where data will be collected are specified. According to Saunders et al. (2009) "every research falls into the following three categories: Descriptive, Explanatory (causal), and Exploratory".

A case study approach was chosen to assess the credit risk management strategies of Adansi Rural Bank Limited. The choice of this approach was to enable the researcher to conduct an enquiry into the set of related events in Adansi Rural Bank with the objective of explaining and describing the subject matter of interest. The research design also facilitates an in-depth analysis of the phenomenon under study. A series of face-to-face interviews were conducted with senior credit officers whiles data on the extension of credit facilities to borrowers and non-performing loans were obtained from the annual reports of the rural bank which was made accessible to the researcher by officials of Adansi Rural Bank.

\subsubsection{Population of Study}

Population refers to the universe of units from which the sample is to be selected (Ofori\&Dampson, 2011). Nachmias and Nachmias (1992) define a population as "the aggregate of all cases that conform to some designated set of specification" whiles the sample frame is the material or device from which a sample is drawn. According to Mason et al. (1997), the population of a study is the collection of all possible individuals, objects or measurements of interest. For this research work, all senior credit officers of Adansi Rural Bank Limited will represent the population of the study. This comprises of the credit management department and certain key 
management departments of the bank. These respondents were chosen because are in a better position to offer firsthand information on credit management practices that are carried out in Adansi Rural Bank.

\subsubsection{Sample Size and Sampling Techniques}

Sampling refers to the researcher's decision on which target group, settings, events or behaviour to observe in carrying out the study successfully. In order to obtain accurate and reliable information on credit risk management practices of the rural bank, the researcher adopted a purposive sampling technique to interview the targeted group. The researcher considered this sampling technique as the most appropriate for the study because information on credit risk involves technicalities and this requires the requisite knowledge and experience of credit management officers whose primary responsibility is centered on credit risk management. Apparently, the size of the sample and the sampling technique certainly has implications on the confidence in the results and the extent to which generalizations are made for the study.

\subsubsection{Data Sources and Collection Instrument}

Sampling techniques give the researcher the opportunity to choose from a range of methods that will help the researcher to collect the most appropriate quantity of data needed to successfully conduct a study, Saunders et al (1997). A sample size of forty (40) respondents was selected for the study. A purposive sampling technique was used to select the respondents. The researcher employed the purposive sampling technique in sampling the respondents. Purposive sampling represents a group of different non-probability sampling techniques. Purposive sampling is also referred to as selective or subjective and judgemental sampling. Purposive sampling relies on the judgment of the researcher when it comes to selecting the units (e.g., people, cases/organizations, events,) that are to be studied.

Table 1. Distribution of respondents for the four selected branches of Adansi rural bank limited

\begin{tabular}{lcc}
\hline Branch & \multicolumn{2}{c}{ Sample Size (Staff) } \\
\hline Percentage of Sample (\%) & & \\
Atonso & 9 & 22.50 \\
Kaase & 6 & 15.00 \\
Kotwi & 3 & 7.50 \\
Asokwa & 22 & 55.00 \\
Total & 40 & 100.00 \\
\hline
\end{tabular}

Respondents were selected from four (4) branches of the bank in Kumasi: Atonso , Kaase, Kotwi and Asokwa. The table displays the number of respondents in each of the four branches of Adansi rural bank limited.

\subsubsection{Data Analysis Methods}

The data collected was processed by editing and coding to eliminate all errors. The collected data was then analysed using both qualitative and quantitative analytical techniques to draw valid conclusions and inferences. This was carried out using Statistical Package of Social Sciences (SPSS) version 17.0. Cross tabulations were used to bring-out all interrelated inferences. With the quantitative technique, percentages, tables, charts and graphs were employed. With the qualitative analysis, descriptions were used it explaining the data phenomenon. The findings and recommendations of the analysed data will be used for the formulation and implementation of policies.

\subsection{Organizational Profile of Adansi Rural Bank Limited}

Adansi Rural Bank is a Limited Liability Company that was established in 1980.The company was established in line with the companies code 1963, Act 179.Adansi Rural Bank Limited operates within the limitations and structure as specified in the Banking Act 2004, Act 673. Adansi Rural Bank Limited has a headquarters in Fomena, in the Ashanti Region. The headquarters is located about 58 kilometres southwards on the Cape Coast-Kumasi Highway. Adansi Rural Bank currently has nine branches.The rural bank has six branches in Kumasi. The branches in Kumasi are located in Dunkirk, Atonsu, Kotwi, Kaase ,Mbrom and mobilization centre at Asokwa. Fomena, Obuasi, Akrokerri, and New Edubiase are other branches of Adansi Rural Bank which are located outside Kumasi.

\section{Introduction}

\subsection{Data Presentation, Analysis and Discussion of Findings}

This chapter gives an overview of data presentation, analysis and discussion of the data collected based on the 
methodology adopted for the study. The analysis is aimed at presenting the findings from the field work. The areas covered under this chapter include; socio-economic statistics of the respondents. It goes further to examine the credit risk policy of Adansi Rural Bank Limited, lending evaluation, monitoring and intervention processes to recover overdue credit and identify the challenges encountered by Adansi Rural Bank Limited in credit risk management.

\subsubsection{Socio-Economic Statistics of Respondents}

The researcher gave out sixty (60) questionnaires to the four (4) branches of Adansi Rural Bank but forty (40) questionnaires were responded to by the respondents. The table and figure below illustrates the socio-economic statistics of the respondents.

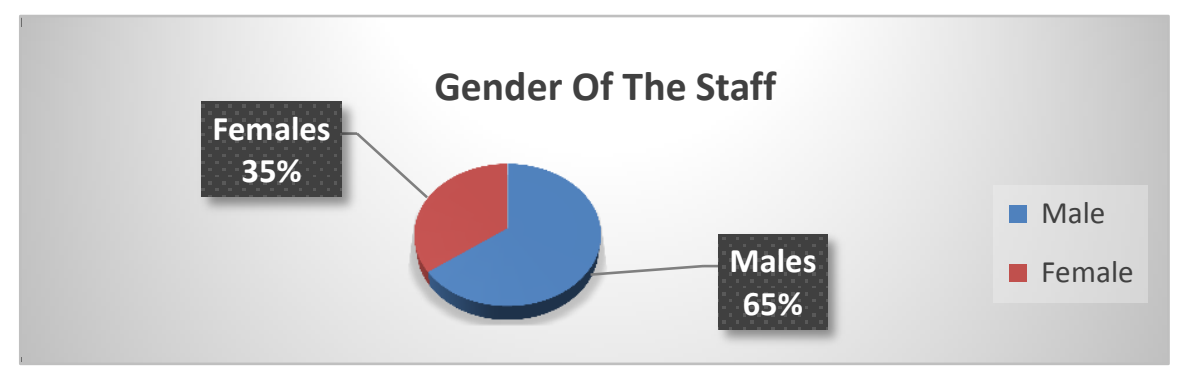

Figure 3. Gender of the staff

Figure 3inferrs that the males were (26) representing $65 \%$ whiles the females were (14) representing $35 \%$.

Table 2. Socio-economic characteristics of the staff of the bank

\begin{tabular}{lcc}
\hline Variable & & \\
\hline Frequency (40) & 0 & Percentage (\%) \\
\hline Age & 12 & 0.00 \\
Below 25 & 13 & 30.00 \\
$25-30$ & 15 & 32.50 \\
$31-35$ & & 37.50 \\
40 years and above & 0 & \\
Qualification & 18 & 0.00 \\
SHS Certificate & 22 & 45.00 \\
Diploma & 0 & 55.00 \\
Degree & & 0.00 \\
No formal education & 5 & 12.50 \\
Work experience & 16 & 40.00 \\
1-5 yrs & 12 & 30.0 \\
6-10 yrs & 7 & 17.50 \\
$11-15$ yrs & & \\
15 yrs and above & 3 & 7.50 \\
Marital status & 26 & 65.00 \\
Single & 5 & 12.50 \\
Married & 2 & 5.00 \\
Separated & 4 & 10.00 \\
Divorced & & \\
Widowed & & \\
\hline
\end{tabular}

Table 2 shows the socio-economic characteristics of the respondents. From this Table, it can be seen that, none of the respondents is below 25 years. But 12 out of 40 of the respondents, representing 30 percent are of ages between 25 years to 30 years. Also, 13 out of 40 of the respondents representing 32.5 percent were between 31 to 35 years. But a large number of 15 out of the 40 respondents, representing 37.5 percent were 40 years and above. 
The study showed that all the respondents have had formal education. The results clearly show an astounding 40 respondents, representing 100 percent have had tertiary education. There was no record of any respondent holding a senior high school certificate or any lower certificate. Majority of them thus 35 out of 40 representing 87.5 percent have work experiences and have worked with the bank from 6 years to 15 years and above leaving only 5 out of 40 representing 12.5 percent of the them having work experience of 1 year to 5 years. The results also show that 26 out of 40 representing 65 percent of the respondents were married.

\subsubsection{An Assessment of the Credit Risk Policy of Adansi Rural Bank Limited}

According to the head of operations of Adansi Rural Bank, credit risk policies are to mitigate the impact of credit risk on the operation of the rural bank. The credit risk manager is assigned with the exacting task of conducting periodic review of the procedures adopted by the credit officers of the rural bank. This is to ensure that strict credit policies are adhered to by all credit officers at all times.

\subsubsection{Does Adansi Rural Bank have a Credit Policy for Managing Loan Portfolio Risk?}

Bank of Ghana has directed all financial institutions in the country to have rigorous loan portfolio management systems. The directive stated that should be 1 percent of the entire loan portfolio. Adansi Rural Bank controls its credit procedures in a manner that the final outcome will be a maximum credit impairment of 1 percent of the loan credit portfolio of the rural bank. This is in accordance with the directive of the central bank. Table 4.1 shows the responses from the respondents when they were asked whether there was a credit policy for managing a loan portfolio risk.

Table 3. Credit risk policy of Adansi rural bank

\begin{tabular}{ccc}
\hline Statement & \multicolumn{2}{c}{ Response } \\
\cline { 2 - 3 } & Frequency & Percentage \% \\
\hline Yes & 37 & 92.50 \\
No & 3 & 7.50 \\
Total & 40 & 100 \\
\hline
\end{tabular}

The extension of credit is the chief source of income for Adansi Rural Bank. Therefore the modus operandi by which credit risk exposures is managed can have an impact on the growth and the going concern of the rural bank. It was evident in the responded questionnaires that Adansi Rural Bank has clearly written instructions on the credit risk management procedures. A large number of the respondents thus 37 out of 40 , representing 92.5 percent affirm that the rural bank has written instructions on the credit risk management procedures.

Adansi Rural Bank's credit policy is embedded with guidelines on issues such as: the goal of the credit policy, risk recognition, monitoring and control, credit approval levels at various stages of authority, risk acceptance criteria, loan documentation processes, target market, role and responsibilities of staff are into the initiation and management of credit, portfolio mix, reporting standards, pricing and non-pricing terms and management of default loans. This document is expected to serve as a directive to all credit officers of the rural bank.

It is obvious that having a documented credit policy is a step in the right direction, however it is just the first step, effectiveness of the policy implementation is the challenge. Not handling the credit risk function well can pose a serious threat to a financial institution's survival, with a resulting negative impact on the interest of depositors and other relevant stakeholders.

\subsubsection{The Review of the Credit Policy at Adansi Rural Bank Limited}

The study also shows how often Adansi Rural Bank Limited reviews its credit policies. A large number of the respondents representing 36 out of 40 , thus 90 percent affirmed that the rural bank conducts annual credit policy review. A small number, representing 10 percent, thus 4 out of 40 stated that the credit policy review was conducted quarterly. The difference recorded in the time of credit policy review can be attributed to the fact that, some of the branches were not following the annual review directive given by the rural bank. It is also possible that these respondents made a mistake when answering the questionnaires.

\subsubsection{Satisfactory Level of Credit Risk Policy at Adansi Rural Bank Limited}

The study shows whether the respondents are satisfied with the credit risk management policies of the rural bank. The table below shows the responses given by the respondents when they were asked whether they were satisfied with the credit risk policy of the rural bank. 
Table 4. Satisfactory level of the credit risk policy of Adansi rural bank limited

\begin{tabular}{ccc}
\hline Statement & \multicolumn{2}{c}{ Response } \\
\cline { 2 - 3 } & Frequency & Percentage \% \\
\hline Yes & 34 & 85.00 \\
No & 6 & 15.00 \\
Total & 40 & 100 \\
\hline
\end{tabular}

In Table 4 above, a vast majority of the respondents, thus 34 out of 40 representing 85 percent of the respondents were satisfied with the credit risk management. This actually confirms the fact that Adansi Rural Bank Limited has developed a credit risk management policy that guides the management of their loan portfolio.

\subsection{Factors That Are Considered in Establishing a Loan Policy at Adansi Rural Bank Limited}

Through this study, factors that are considered by Adansi Rural Bank when developing loan portfolio policies were discovered. On a scale of 1 and 4, where 1 denotes very often and 4 represents not at all. The result is represented by the figure below.

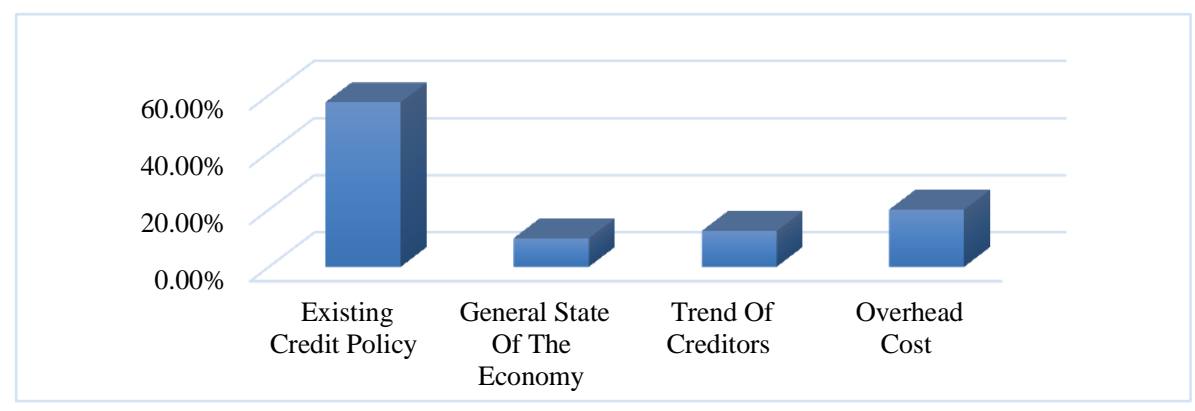

Figure 4. Considerations in establishing a loan policy at Adansi rural bank limited

From figureabove, the results show that an overwhelming majority of the respondents responded that the existing credit policy is considered very often when developing the credit policy of the rural bank. This factor was the highest response, representing 23 out 40 thus 57.5 percent. The overhead cost was the second factor that was considered when the rural bank prepares a credit policy. Twenty percent of the respondents chose this option, representing 8 out of 40 respondents. The trend of the creditors was the third factor that was considered and it represented 5 out of 40 , thus 12.5 percent.

The general state of the economy was the last factor that was considered. The response of the respondents showed that 4 out 40 respondents representing 10 percent affirmed that the general state of the economy was considered in the preparation of a credit policy in the rural bank.

\subsubsection{How Often the Following Credit Risk Management Measures Are Used by Adansi Rural Bank Limited}

The study also showcased how often; collateral security; strict enforcement of restrictive covenant; Guarantees and Credit insurance are considered before a credit facility is approved.

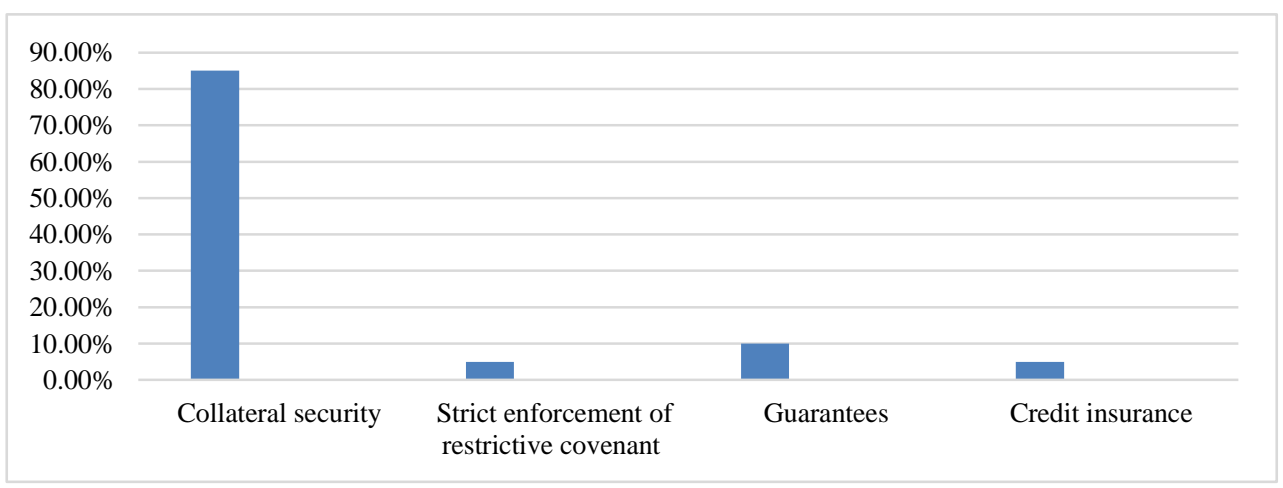

Figure 5. Credit consideration measures at Adansi rural bank limited 
The figure above shows the response of the respondents to this question.

The results from the four branches of the rural bank clearly show that Adansi Rural Bank exceedingly considers collateral security over all the other measure put in place to mitigate credit risk exposures. The results above show that 34 out of 40 respondents, representing an overwhelming 85 percent confirmed that collateral security was the most considered when assessing a loan application. A guarantee was the second measure which was considered after collateral security. Four (4) out of forty (40) respondents, representing 10 percent affirmed the fact that a guarantee was the most used measure after collateral security. It was quite surprising that consideration of strict enforcement of restrictive covenant and insurance both recorded the same percentage response of 2 out of 40 respondents, representing 5 percent.

\subsubsection{Parties Involved in Formulating Credit Risk Management Policies at Adansi Rural Bank Limited}

The study threw more light on the parties involved in the formulation of the credit risk management policies of the rural bank. The respondents were asked to tick $(\sqrt{ })$ the extent to which they agree or disagree with the formulation of credit risk management policies in the rural bank. The illustration represents the responses of the respondents.

Table 5. Parties involved in formulating credit risk policies inAdansi rural bank limited

\begin{tabular}{lcccccc}
\hline Party & \multicolumn{9}{c}{ Response } & \multirow{2}{*}{ Total } \\
\cline { 2 - 5 } & SD & D & U & A & SA & \\
\hline Executive management & 2 & 3 & 2 & 15 & 18 & 40 \\
Board of directors & 1 & 3 & 4 & 17 & 15 & 40 \\
Credit committee & 2 & 4 & 2 & 13 & 19 & 40 \\
Credit managers & 2 & 2 & 3 & 18 & 15 & 40 \\
Employees & 1 & 3 & 4 & 15 & 17 & 40 \\
Rating Response & 8 & 15 & 15 & 78 & 84 & \\
\hline
\end{tabular}

The results show that the credit committee of Adansi Rural Bank Limited and the credit managers were excessively involved in the risk identification process. The study also showed that the board of directors, executive management and the employees following in their respective order are involved in the risk identification process.

\subsubsection{Evaluating Lending, Monitoring and Intervention Processes to Cover Overdue Credit}

The study brought to light the lending, monitoring and intervention processes of Adansi Rural Bank. The objective was to uncover the strategy the rural bank applies in managing overdue loan portfolio.

\subsubsection{Evaluation of Lending Process at Adansi Rural Bank Limited}

During loan appraisal, factors considered relevant during this process can be limited to when borrower's character, condition, collateral, capital, capacity and control are properly evaluated. In a case where a borrower falls short of any of these requirements, a rigorous investigation should be carried out before credit is extended to the borrower. If the rural bank places great emphasis on the five C's, it will be a good position to select credit worthy customers. The figure below shows the response of credit officers when asked to indicate the extent to which the various considerations were applied in loan appraisal.

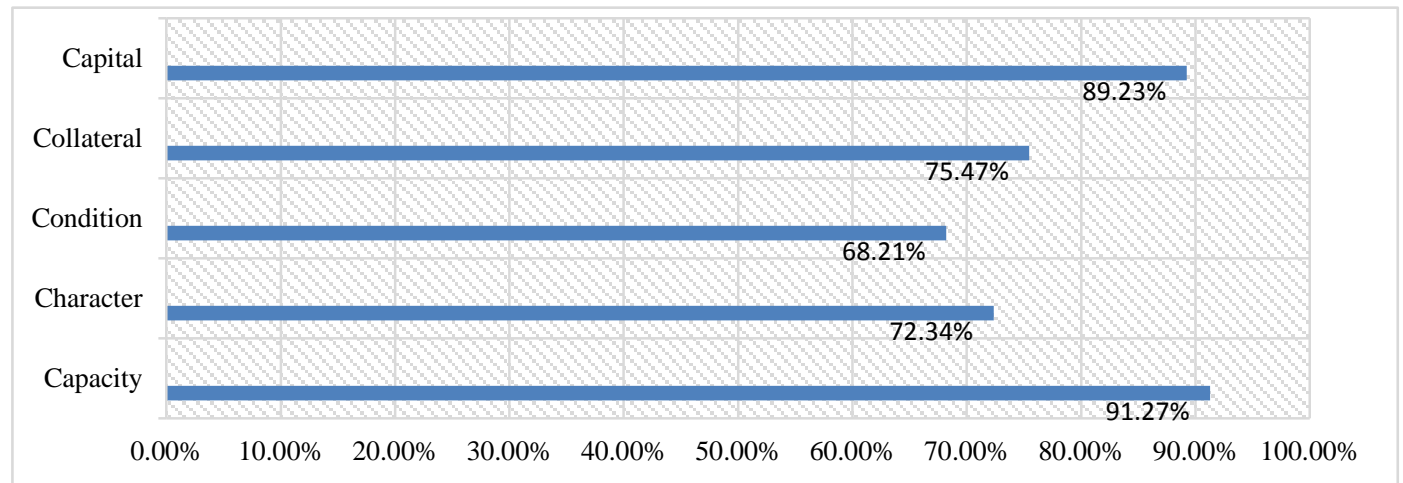

Figure 6. Lending process evaluation at Adansi rural bank limited 
The results show that 91.27 percent of the respondents believe that a borrower's capacity is important whiles 8.73 percent of them think otherwise. Secondly, 72.34 percent of the respondents also believe that a borrower's character is of importance whiles 27.66 percent think otherwise. With borrower's condition, 68.21 percent of the respondents see it as important but 31.73 percent consider it to be irrelevant.Again, 89.23 percent of the respondents think the borrower's capital is necessary whiles 10.77 percent responded that it is are not necessary. Finally, 75.47 percent of the respondents believe borrower's collateral is a relevant condition but 24.53 believe it is irrelevant.

The results above clearly shows that, all four branches of Adansi Rural Bank consider the Five C's as an integral component in loan appraisal. The rural bank has a centralized credit system which is buttressed by technology. The lending process is carried out by the credit department. The Relationship Manager analyses the borrower by assessing the borrower's capacity, character, condition, control, capital and collateral. The relationship manager then collects information on the borrower and proceeds further to prepare a proposal for the borrower. An assessment is carried out by evaluating the borrower's business, evaluating the risk associated with the borrower's business and examining any write-up that has been put together and based on these assessments a decision is made. The loan application is either approved or disapproved.

The request is forwarded to the head of the final credit administering department who analyze and see to it that the appropriate appraisal techniques were applied. The borrower is then granted the credit facility after the loan application has been approved.

Most of the respondents attested to the fact that there is no third party that influences the final decision made on the applied loan. Lastly, the collateral security is taken into consideration. They come in so many forms such as guarantee, physical property, etc. depending on the kind of facility which is being given to the borrower. With salaried workers however, the source of repayment is the salary and the collateral security is the undertaking the borrower's company/employer will sign to give assurance that they will channel the borrower's salary through the bank until the facility is paid. The reputation of the borrower's company/organization is critically evaluated before credit is granted to the borrower and also the amount of credit requested by the borrower in relation to how much the borrower earns.

\subsubsection{Evaluation of the Monitoring Process of Adansi Rural Bank Limited}

Effective monitoring enables credit officers to detect the possibility of a credit default. Through effective monitoring, credit officers can take corrective measures to mitigate credit risk. Without effective monitoring, many uncertainties may be realized which will be extremely difficult to rectify. In an attempt to find out how monitoring of credit is done at Adansi Rural Bank Limited, the credit officers were asked to indicate the extent to which the rural bank undertakes each of the listed procedures regarding the monitoring of borrowers. The table below gives a summary of the results.

Table 6. Monitoring process of Adansi rural bank limited

\begin{tabular}{lcccccc}
\hline Procedures Involved in Monitoring Borrowers & \multicolumn{5}{c}{ Responses } \\
\cline { 2 - 7 } & NA & N & S & M & VM & Total \\
\hline Contactwithborrowers & 0 & 6 & 0 & 16 & 18 & 40 \\
Updateofcreditfiles & 0 & 0 & 8 & 11 & 21 & 40 \\
Monitoringborrowersaccount & 0 & 0 & 5 & 10 & 25 & 40 \\
Cultureofbeing supportive & 6 & 0 & 4 & 12 & 18 & 40 \\
Regularreviewofborrowersreport & 2 & 0 & 7 & 9 & 22 & 40 \\
RatingResponse & 8 & 6 & 24 & 58 & 104 & \\
\hline
\end{tabular}

From Table 6 above, 45 percent of the respondents have contact with borrowers, 40 percent as well have contact but not that frequent and 15 percent don not have any contact with borrowers. Cumulatively, the findings again show that 80 percent of the respondents frequently update borrower's credit files thus both much and very much. 20 percent do not really update borrower's credit files.

Considering the flow of borrower's business, most 60.53 percent frequently do that whiles 25 percent monitor but not frequently.14.47 percent somehow do same through the client's banks account. When it comes to the development of the culture of supporting borrowers, 30 percent of the respondents do so frequently whiles 45 percent of them do much better. 15 percent do not do that at all and 10 percent somehow do that. 77.5 percent of the respondent regularly review borrowers report, 17.5 percent do so somehow while 5 percent do not do that at all. 
The findings reveal that; majority of the banks consider having frequent contact with borrowers as a major monitoring tool to reduce the bank's risk exposure. The least important factor is the development of the culture of being supportive to borrowers when they are in financial difficulties. This shows that, the rural bank considers these factors. Concerning the effectiveness of the monitoring processes of the Adansi Rural Bank, most of the respondents considered it to be very effective because, the control mechanisms put in place to monitor credit facilities assessed by borrowers. Other respondents considered it to be appropriate because credit officers are assigned to carry out the monitoring process and this had resulted in minimal credit defaults. Few of the respondents had no idea about the effectiveness of the monitoring process their organization uses.

During the interview with the respondents, the researcher noticed that, monitoring of credit facilities is primarily done by the branch of the rural bank that generates the credit even though the approval of the loan usually comes from the head office in Fomena.

It is a shared responsibility right from the relationship manager to all the credit officers under credit department. Credit officers monitor the loan portfolio and ensure that the loans in the portfolio do not go bad. The relationship manager or officer is responsible for the monitoring of extended credit to borrowers. The relationship officer occasionally contacts borrowers, visits projects sites, with the aim of ensuring that the extended credit is used for the intended purpose.

The credit department updates borrower's credit files and periodically reviews borrowers rating .The study shows that credit officers monitor the operations of businesses of borrowers through the bank account of borrowers and usually support borrowers when they are in financial difficulties. The monitoring of salaried workers is quite different. The credit facility is monitored by the relationship manager who regularly visits the employer of the borrower makes sure that the borrower is still working with the employer. The relationship manager enquires the duration the borrower has spent working with the employer among other relevant enquiries. The credit evaluation manager, as a form of monitoring makes enquiries from the relationship manager frequently about the borrower. Also the credit administration officers monitor the accounts of the borrowers and inform the credit department of any new development.

\subsection{Interventions to Recover Overdue Credit}

Most studies indicate that interventions to recover overdue credit are of less importance once the lending and monitoring processes are appropriate. Interventions enable the rural bank to retrieve credit from borrowers who have defaulted in loan repayment. Usually the implementation of interventions by rural banks varies immensely. ger and Udell (2002), the basic tools for controlling losses are collateral, covenants, credit rationing, loan syndication and loan securitization. Rural banks can consider these in addition to other interventions. Table 5.3 summarizes the findings on interventions.

Table 7. Controlling credit losses

\begin{tabular}{lcccccc}
\hline Measures for Controlling Credit Loss & \multicolumn{9}{c}{ Response } \\
\cline { 2 - 7 } & NA & N & S & M & VM & Total \\
\hline LoanSyndication & 17 & 4 & 3 & 2 & 14 & 40 \\
LoanSecuritization & 0 & 4 & 7 & 16 & 13 & 40 \\
CreditRationing & 6 & 2 & 4 & 17 & 11 & 40 \\
Collateral & 0 & 0 & 5 & 14 & 21 & 40 \\
Covenant & 0 & 2 & 3 & 15 & 20 & 40 \\
Ratingof Responses & 30 & 38 & 53 & 92 & 104 & \\
\hline
\end{tabular}

From the table above shows 52.5 percent of the respondents do not use loan syndication. 35 percent use it very much whiles 5 percent uses it much. 7.5 percent somehow use loan syndication. 40 percent frequently use loan securitization. 32.5 percent most frequently consider it whiles 10 percent do not use it. The study also shows that 42.5 percent of the respondents frequently use credit rationing as a tool in controlling losses while 27.5 percent use this same tool more frequently. 10 percent somehow consider it and 20 percent do not use it at all.

52.5 percent of the respondent most frequently use collateral to control credit losses. 35 percent agree they use collateral as a tool but not that frequent. 12.5 percent somehow use it and none use it at all. 50 percent strongly agree to using covenants as a tool. 37.5 percent agree while 7.5 percent somehow agree and finally 5 percent do not really consider it as a tool in controlling credit losses.

From the study it was discovered that the four branches of Adansi Rural Bank make use of collaterals, covenants, 
credit rationing and legal actions to recover their overdue credits. However, loan syndication and loan securitization that have proofed to be very useful in Europe have not been widely considered.

The loan syndication is used by the banks to reduce the amount of loss they face by sharing the risk with other banks. Loan securitization is when a pool of assets of borrowers is readily sold to recover overdue credit. Some of the banks have rehabilitation departments who try to restructure the loan requirements of default borrowers as a way of recovering their loans. Normally restructuring is carried out to reduce the burden of paying bulk sums. It helps in settling debt on flexible terms whiles protecting the interest of both the borrower and the lender. This can be carried out promising to reward faithful borrowers with packages once they are done paying their debts.

\subsubsection{The Challenges Encountered by Adansi Rural Bank Limited in Credit Risk Management Practice}

Adansi Rural bank is exposed to many challenges when managing credit risk exposures. The difficulty in locating borrowers as a result of poor address systems is one of the challenges. The never ending bureaucracy in obtaining authorization to sell collateral is a major challenge. The rural bank usually undergoes complicated processes before obtaining the legal right to sell the collateral. Adansi Rural Bank is incurs high cost in monitoring borrowers.

The four (4) credit managers in the four branches of Adansi Rural Bank were asked to indicate the challenges the rural bank is exposed to in the management of credit risk. It was revealed in the interview that; insufficient information on loan applicant is considered to be one of the challenges Adansi Rural Bank is exposed to in the management of credit risk. Generally information on customers in Ghana is difficult to access so accurate information is hard to come by. This makes loan recovery extremely gruesome.

The study also unveiled that lack of credit referencing of loan applicants usually leads to borrowers accessing multiple loans in other financial institutions. It was disclosed that most of the borrowers access multiple credit facilities from many financial institutions which are unknown to credit officers of Adansi Rural Bank. Multiple debt obligation of borrowers in the long term results in loan defaults. The respondents indicated that occasional delay in the approval of credit by the credit committee is a challenge. This challenge was attributed to the fact that most of the credit committee members are directors and due to their busy schedule, they are not able to meet regularly as required to approve loans for clients to meet their intended time frame for the purpose of the loan. This sometimes affect their loan repayment as market forces like a depreciating exchange rate has negative impacts when on customers involved in import and export trade.

\subsubsection{Loan Advancement and Non-Performing Loans at Adansi Rural Bank Limited}

The respondents were asked to provide their total loan advancement and non-performing loan from year 2011 to 2016. This analysis seeks to establish the pattern of the loan advancement and non-performing loans of Adansi Rural Bank Limited within a five year period.

Table 8. The loan advancement trend and non-performing loans (2011-2016)

\begin{tabular}{cccc}
\hline Year & Net Loan $(\mathrm{Gh} \ell)$ & Impairment $(\mathrm{Gh} \ell)$ & Ratio of impairment to the total loan portfolio \\
\hline 2011 & $1,288,638.08$ & $20,126.00$ & $1.6 \%$ \\
2012 & $3,980,978.73$ & $79,997.00$ & $2 \%$ \\
2013 & $6,747,026.38$ & $117,105.00$ & $1.7 \%$ \\
2014 & $8,463,705.35$ & $56,310.00$ & $0.7 \%$ \\
2015 & $1,012,346.13$ & $23,717.00$ & $2.3 \%$ \\
2016 & $7,878,737.78$ & $17,635.00$ & $0.22 \%$ \\
\hline
\end{tabular}

Table 8 shows that provisions were made for credit losses within the five year period, and these were expressed as a percentage of the total loan portfolio.

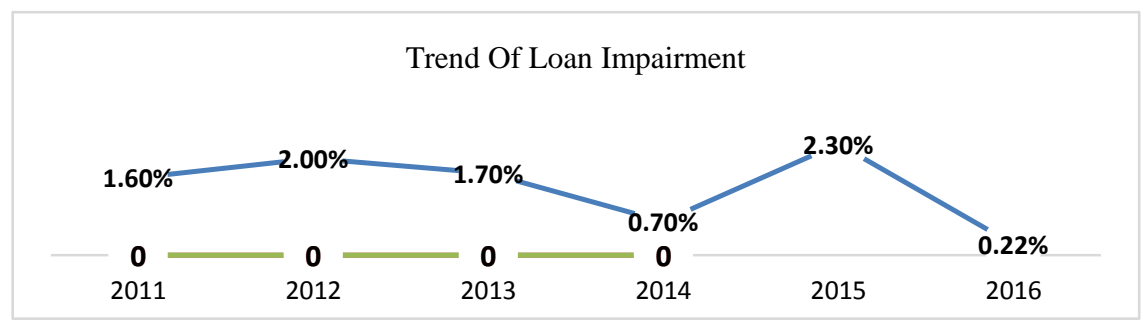

Figure 7. Trend of loan impairment (2011-2016) 
The percentage values for the duration of $2011-2016$ were $1.6 \%, 2 \%, 1.7 \%, 0.7 \%, 2.3 \%$ and $0.22 \%$ respectively. The ratio was quite high initially but it became quite worrying when it rose from $1.6 \%$ in 2011 to $2 \%$ in 2012 . The ratio however declined significantly from the previous figure of $1.7 \%$ in 2013 to $0.7 \%$ in 2014 but surprisingly, it rose again in 2015 to $2.30 \%$ but it declined in 2016. A fall in the ratio denotes a significant improvement in the quality of the loan portfolio. This can be attributed to renegotiated loans in the previous year and improvement in loan recoveries. Form the table, in 2014, there was a remarkable improvement in the quality of the loan portfolio as low as $0.7 \%$ of the total loan was recorded as non-performing. This success was achieved because management anticipated the growing trend in the non performing loans ratio so management initiate and implement policies reduced the growing trend.

\subsubsection{The Implications of Non-Performing Loans}

The interest generated from loans contributes significantly to the financial performance of rural banks. However, in situations where loans are delinquent, the impact it has on the financial health of the rural bank is unpropitious.

\section{Introduction}

\subsection{Summary of Findings, Conclusion and Recommendations}

This chapter presents an overview of the study and briefly discusses the findings, from which conclusions are made and recommendations proffered for improvements in the credit risk management practices of Adansi Rural Bank Limited. The chapter summarizes the entire study; the findings of the study, the recommendations of the researcher, limitations encountered and directions for future research in this field.

\subsection{Summary of Findings}

This study assesses the various credit risk management practices and policies adopted by Adansi Rural Bank Limited in managing, the rural bank's Loan Portfolio Performance. Specifically, the research objectives are to; examine the credit risk policy of Adansi Rural Bank Limited; evaluate lending, monitoring and interventions to recover overdue credit; identify the challenges encountered by Adansi Rural Bank Limited in credit risk management.

The research examined the effect of credit risk management on the quality of the loan portfolio of Adansi Rural Bank Limited. The study evaluates the extent to which the implementation of the various credit risk management practices by the rural bank has decreased the number of non-performing loans. The study shows that Adansi Rural Bank Limited has a rigorous credit risk management policy that is in operation. Adansi Rural Bank Limited has clear guidelines on how to approach and deal with the credit risk exposures in managing credit. The study shows that the development of the credit policy is largely based on the existing credit policy. Other factors that were considered were trends of creditors, the state of the economy and overhead costs. Again the study uncovered the practices Adansi Rural Bank carries out to mitigate credit risk exposures. It was evident in this study that Adansi Rural Bank depends on collateral security, strict enforcement of restrictive covenant, guarantees, legal actions and credit insurance in mitigating credit risk exposures.

The study shows the volatility in the credit advance trend of Adansi Rural Bank. However, this impressive credit expansion drive is being endangered by the increases in non-performing loans. The Rating System was instrumental in rating the reliability of Adansi Rural Bank. Capital adequacy, liquidity and earnings are essential components in rating the reliability of the rural bank. Management efficiency and asset quality were also proven to be substantial but not as equally significant as capital adequacy, liquidity and earnings.

The findings also show that, Adansi Rural Bank uses interventions which are effective and capable of recovering credits when borrowers default in loan repayment. The rural bank uses credit rationing, covenants and loan securitization as tools to mitigate credit risk exposures. Not many rural banks consider the application of loan syndication.

\subsection{Conclusion}

Adansi Rural Bank has a clearly written credit risk management policy in place with the board of directors having oversight responsibility for its execution. In the quest of Adansi Rural Bank to reduce the non-performing loans of the total loan portfolio. Adansi Rural Bank has skewed the extension of credit facility to players in the agriculture sector which is one of the rural bank's core values to extending credit facility to salaried workers, in the form of salary loans, public sector employee loan facility and business expansion loans and school fees loans. This skewness is mainly as a result of the high risk exposures associated with extending credit to players in the agricultural sector. 


\subsection{Recommendations}

Based on the discussions and the findings, the researcher recommends that Adansi Rural bank should work in partnership with credit reference bureaus in the country. This will enable the rural bank to effectively access adequate information on loan applicants and identify credit worthy loan applicants there by mitigating credit risk exposures. The rural bank should consider creating a loan recovery department that will be sorely responsible for recovering overdue loans. The rural bank should ensure that credit officers monitor customers regularly to ensure that credits accessed by borrowers are used for the intended purpose.

Again credit officers should ensure that borrowers have a clean legal title to their collateral so that the rural will take full possession without any cost in case the borrower defaults in the repayment of the loan. Also there should be regular meetings between the credit committee members of the rural bank so that approval of loan applications will meet borrowers request on time. Finally, Adansi Rural Bank should adhere to the loan policies and desist from any human intervention if the necessary requirements are not met.

In summary the bank should:

1) Consider working hand in hand with credit reference bureau in the country to thoroughly examine the records of loan applicants so as to reduce the rate of default.

2) Reduce and if possible eliminate all forms of political influence associated with the granting of credits to certain political figures and organizations. This will ensure that the bank has control in granting credit and also ensure that loans are granted to creditworthy borrowers.

3) Adhere strictly to loan policies and discourage any human interventions if necessary requirements are not met.

\subsection{Recommendation for Further Studies}

- Current studies lack detailed information on interventions to recover overdue credit. Further studies can therefore be conducted in this dimension.

- Policy makers and the authorities in government should approve policies that will set up a database that will be updated frequently to consider names, location and movements, and all other relevant profile of citizens of the country. This will provide relevant information that rural banks can access the credit worthiness of customers and also locate credit defaulters.

\section{References}

Abdelrahim, K. E. (2013). Effectiveness of Credit Risk Management of Saudi Banks in the Light of Global Financial Crisis: A Qualitative Study. Asian Transactions on Basic and Applied Sciences, 3(2), 73-91.

Abdul, H., Kuo, H., Wang, L., Lai, Y., \&Yu. (2014). Loan policy and bank performance: evidence from Taiwan. Journal of Banks and Bank Systems, 5(2), 11-35.

Abiola, I., \& Olausi, A. S. (2014). The Impact of Credit Risk Management on the Commercial Banks Performance in Nigeria. International Journal of Management and Sustainability, 3(5), 295-306.

Abreu, M., \& Mendes, V. (2000). Commercial bank interest margins and profitability: Evidence from E.U countries. Porto, working paper series.

Ahmad, N. H., \& Ariff, M. (2007). Multi-country study of bank credit risk determinants. International Journal of Banking and Finance, 5(1).

Ahmad, R., Ismail, A.G.,\& Shaharudin, R.S. (2004). The Response of Capital Adequacy Requirement On Loan Loss Provision and Realized Security Gain.

Akmalia, M. A., Muhd, K. I., \& Radiah, O. (2007). Determinants of firm level governance: Malaysian evidence. Corporate Governance: The International Journal of Business in Society, 7(5), 562-573. https://doi.org/10.1108/14720700710827158.

Allen, L., \& Bali, T.G. (2004). Cyclicality in Catastrophic and Operational Risk Management. Working Paper.

Al-Smadi, M. O., \& Ahmed, N. H. (2009). Factors Affecting Banks' Credit Risk: Evidence from Jordan. Malaysia: Collage of Business, University Utara Malaysia.

Andersen, T. J. (2006). Perspectives on strategic risk management. Copenhagen Business School Press, DK

Apanga, M. A. N., Appiah, K. O., \& Arthur, J. (2016). Credit risk management of Ghanaian listed banks. International Journal of Law and Management, 58(2), 162-178. https://doi.org/10.1108/IJLMA-04-2014-0033 
Ariff, A. M., Ibrahim, M. K., \& Othman. (2007). Determinants of firm level governance: Malaysia evidence.The International Journal of Business in Society, 7, 562-573.

Asenso-Okyere, W. K., Asante, F. A., \& Gyekye, O. (2014). Policies and strategies for poverty alleviation in Ghana. Accra: ISSER.

Asiedu-Mante, E. (2011). Financial Markets in Ghana. Lagos: WAIFEM, Central Banking and Bank Distress.

Athanasoglou, P. P., Delis, M. D., \& Staikouras, C. K. (2008). Determinants of Bank Profitability in the South Eastern European Region. Bank of Greece, Working Paper No. 47.

Basel Committee on Banking and Supervision.(1999).Principles for the management of credit risk. Consultative paper issued by the Basel Committee on Banking Supervision, Basel.

Basel Committee on Banking and Supervision. (2000). Best practices for credit risk. Basel Committee Publication No. 74, Basel.

Basel Committee on Banking and Supervision. (2001). Sound practices for the management of operational risk. Basel Committee Publication No. 86.

Berk, J. M., \& Bikker, J. A. (2010). International interdependence of business cycle in manufacturing industry: The use of leading indicators for analysis and forecasting. Journal of Forecasting, 14(1), 1-23. https://doi.org/10.1002/for.3980140102

Bluhm, C., Overbeck, L., \& Wagner, C. (2002). Credit Risk Modeling. New York, NY: Wiley.

Bluhm, C., Overbeck, L., \& Wagner, C. (2003).Credit Risk Modeling. New York, NY: Wiley.

Bouvatier, V., \& Lepetit, L. (2007). Provisioning Rules and Bank Lending: A Theoretical Model.

Brown, A. (2004). The Origins and Evolution of Credit Risk Management. Retrieved from http://www.eraider.com/images/articles/RiskHistory1.pdf

Business \& Financial Times. (March 28, 2014). BOG urges Banks to adhere to credit guidelines. Retrieved from http://www.thebftonline.com

Casu, B., Girardone, C., \& Molyneux, P. (2006). Introduction to Banking. England: Pearson Education Ltd.

Comptroller of the Currency. (2011). Note on Categories of Risk taken from the Office of the Comptroller of the Currency's definitions, US Government.

Djiogap, F., \& Ngomsi, A. (2012). Determinants of Bank Long-Term Lending Behavior in the Central African Economic and Monetary Community (CEMAC). Review of Economics \& Finance, 11(3), 1923-1952.

Eastern Caribbean Central Bank report. (May 2009). Guidelines on credit risk management for Institutions licensed to conduct Banking Business under the Banking Act.

Farhan, M., Sattar, A. C., Hussain, A., \& Khalil, F. (2012). Economic Determinants of Non-Performing Loans: Perception of Pakistani Bankers European. Journal of Business and Management, 4(19), 193-220.

Festic, M., Kavkler, A., \& Repina, S. (2011). The Macroeconomic Sources of Systemic Risk in the Banking Sectors of Five New EU Member States. Journal of Banking \& Finance, 5(35), 310-322. https://doi.org/10.1016/j.jbankfin.2010.08.007

Garr, D. K. (2013). Determinants of credit risk in the Banking industry of Ghana: Developing country studies.

Gestel et al. (2009). "Bank Risk Management" Credit Risk Management Basic Concepts: Financial risk components, rating analysis, models, economic and regulatory capital (pp. 55-61). New York: Oxford University Press.

Goldstein, A., Barro, I., \& Gentil, D. (2004). The Role and Impact of Savings Mobilisation in West Africa: A Study of the Informal and Intermediary Financial Sectors in Benin, Burkina Faso, Ghana, Guinea, Mali and Togo. West Africa: MicroSave.

Government of Ghana. (2004). Banking Act, 2004 (Act 673). Ghana Publishing Corporation Accra.

Haron, O. M., Justo, S. M.,Nebat, G. M.,\& Sindani, M. N. (2012). Effectiveness of Credit Management System on Loan Performance: Empirical Evidence from Micro Finance Sector in Kenya.International Journal of Business, Humanities \& Technology, 2.

Hempel, G. H. et al. (2012). Bank Management: Text and Case. New York, USA: John Wiley \& Son.

Hosna, A., Manzura, B., \& Juajuan, S. (2009). Credit risk management and profitability in commercial banks in 
Sweden.

Ibrahim, S., Suki, N. M., \& Harun, A. (2014). Structural Relationships between Perceived Risk and Consumers Unwillingness to Buy Home Appliances Online with Moderation of Online Consumer Reviews. Asian Academy of Management Journal, 19(1), 73-92.

Jimenez, G., \& Saurina, J. (2006). Credit cycles, credit risk and prudential regulation. International Journal of Central Banking, 2(2), 65-98.

Kalapodas, E., \& Thomson, M. E. (2006). Credit risk assessment: a challenge for financial institutions. IMA Journal of Management Mathematics, 17(2), 25-46. https://doi.org/10.1093/imaman/dpi026

Keller, G. (2009). Managerial Statistics Abbreviated (8th ed.). South Western: Cengage Learning

Kithinji, A. M. (2010). Credit risk management and profitability of commercial banks in Kenya. Working paper, School of Business, University of Nairobi, Kenya.

Kwakye, J. K. (2010). High Interest Rates in Ghana. Accra: The Institute of Economic Affairs.

Mason, R. D., Lind, D. A., Marchal, W. G., \& Irwin, R. D. (1999). Statistical Technique in Business and Economics. McGraw-Hill. Boston, MA.

Naceur, S. B., \& Omran, M. (2011). The Effects of Bank Regulations, Competition and Financial Reforms on Banks' Performance. Emerging Markets Review, 12(1), 1-20. https://doi.org/10.1016/j.ememar.2010.08.002

Nair, A., \& Fissha, A. (2010). Rural Banking: the Case of Rural and Community Banks in Ghana. Agricultural and Rural Development Discussion Paper. The International Bank for Reconstruction and Development/World Bank. Washington D.C. https://doi.org/10.1596/27725

Navneet, S., Boopen, S., Sawkut, R., Shalini, R., \& Binesh, R. (2009). Interest Rate Spread Determination in an Error Correction Model.

Ngerebo, T. A. (2011). The impact of foreign exchange fluctuation on the intermediation of banks in Nigeria (1970-2004). African Journal of Business Management, 6(11), 3872-3879.

Nikolaidou, E., \& Vogiazas, S. (2014). Credit Risk Determinants for the Bulgaria

O" Donovan, M. (2004). The Nature Of Risk: Credit Agencies and Light

Oesterreichische National bank. (2006). Guidelines on Operational Risk Management. Austrian Financial Market Authority (FMA).

Ogboi, C., \& Unuafe, O. K. (2013). Impact of Credit Risk Management and Capital Adequacy on the Financial Performance of Commercial Banks in Nigeria. Journal of Emerging Issues in Economics, Finance and Banking, 2(3), 703-717.

Otero, M., \& Rhyne, E. (2011). The New World of Microenterprise Finance. London: IT Publications

Owusu-Frimpong, N. (2008). An evaluation of customers' perception and usage of rural community banks (RCBs) in Ghana. International Journal of Emerging Markets, 3(2), 181-196. https://doi.org/10.1108/17468800810862632

Park, J. (2012). Corruption, soundness of the banking sector, and economic growth: A cross-country study. Journal of International Money and Finance, 31(5), 907-929. https://doi.org/10.1016/j.jimonfin.2011.07.007

$\mathrm{Pu}, \mathrm{X} .$, \& Zhao, X. (2012).Correlation in Credit Risk Changes. Journal of Banking \& Finance, 36(4), 1093-1106. https://doi.org/10.1016/j.jbankfin.2011.11.002

Quagliariello, M. (2007). Banks' riskiness over the business cycle: A panel analysis on Italian intermediaries. Applied Financial Economics, 17(2), 119-138. https://doi.org/10.1080/09603100500486501

Raghavan, R. S. (2003). Risk Management in Banking (pp. 841-851). Retrieved from http://icai.org/resource_file/11490p841-851.pdf

Robinson, M. S. (2001). The microfinance revolution. Washington D.C: World Bank. https://doi.org/10.1596/0-8213-4524-9

Rose, P. (2010). Commercial Bank Management (5th ed). USA: McGraw-Hill/Irwin.

Rose, P. S., \& Hudgins, S. C. (2008). Bank Management \& Financial Series (7th ed.). McGraw Hill/Irwin.

Sarpong, D., Winful, E. C., \& Ntiamoah, J. (2011). Determinants of Wide Interest Margins in Ghana. Panel EGLS Analysis, 3. 
Saunders, M., Lewis, P., \& Thornhill, A. (2007). Research methods for business students (4th Ed). Financial Times Prentice Hall, USA.

Singh, A. (2013). Components of credit risk. Considering a comprehensive credit strategy. Boston, MA: Irwin/McGraw-Hill.

Sullivan, A., Steven, M., \& Sheffrin, S. M. (2003). Economics: Principles in action. Prentice Hall, Upper Saddle River

Thiagarajan, S., Ayyappan, S., \& Ramachandran, A. (2011). Credit Risk Determinants of Public and Private Sector Banks in India. European Journal of Economics, Finance and Administrative Sciences, (34), 147-154.

Van Greuning, H., \& Brajovic-Bratanovic, S. (2010). Analyzing banking risk: A framework for assessing corporate governance and risk management. New York: World Bank Publications

\section{Copyrights}

Copyright for this article is retained by the author(s), with first publication rights granted to the journal.

This is an open-access article distributed under the terms and conditions of the Creative Commons Attribution license (http://creativecommons.org/licenses/by/4.0/). 